\title{
The biographies of leading Belarusian activists in the light of information gathered by the Polish Governmental Commissioner for the City of Vilnius in 1924
}

Outline of contents: In the archives of the Polish Governmental Commissioner for the City of Vilnius, the author of the present study has found reports on fifteen Belarusian activists from the area and beyond: Usyevalad Bil'dzyukyevich, Klawdziy Duzh-Dushewski, Fabiyan Yaremich, Mikhail Kakhanovich, Arsyen Kanchevsky, Mikalay Krasinski, Yazep Lahinovich, Anton Luckevitch, Yazep Mamon'ka, Radaslav Astrovski, Mikhail and Frantsishak Pyatkyevich, Vasil' Rahulya, Symon Rak-Mikhaylowski and Uladzimir Samoyla. The study is supplemented with a note on Boris Kletskin, a Jew who supported the Belarusian movement in Vilnius.

Keywords: All-Belarusian Congress of 1917, Polish borderlands 1918-1939, Vilnius Land 1922-1925, Belarusian activists in the Vilnius Region

The Vilnius Region, placed in the years 1922-25 under the supervision of the Government Delegate, ${ }^{1}$ was home to the largest - second only to the Nowogródek [Navahrudak] area - number of Belarusian communities in the territory of the Polish State. However, the exact percentage of Belarusians among the residents of the Vilnius Land and Poland's other eastern territories cannot be determined precisely, due to, on the one hand, the lack of a crystallised national consciousness, as well as the unfinished process of formation of the Belarusian language at the

\footnotetext{
1 The position of Governmental Commissioner was held by: Władysław Sołtan, Walery Roman (from 6 April 1922 to 29 August 1924), Władysław Raczkiewicz, and Olgierd Malinowski. See also: Act of 22 December 1925 concerning the establishment of the Vilnius Voivodeship, Dz.U. 1926, no. 6, item 29; http://isap.sejm.gov.pl/DetailsServlet?id=WDU19260060029 (access: 6 December 2014). The previous document in force was the Act concerning the seizure of state authority in the Vilnius Land, Dz.U. 1922, no. 26, item 213; http://isap.sejm.gov.pl/DetailsServlet?id=WDU19220260213 (access: 6 December 2014).
} 
time of the census (30 September 1921), and on the other - the criteria adopted during said census.

Moreover, the Vilnius Conference of the Communist Workers' Party of Poland (KPRP) in late 1922 brought the decision of extending the activities of the party by Vilnius and Grodno [Hrodna], ${ }^{2}$ which resulted in the establishment of the Lithuanian-Belarusian branch of the KPRP. The Communist Party of Western Belarus was eventually created in October 1923. The Second Congress of the party recognised the previously denied right of peoples to self-determination, which prompted this party to question Poland's existing eastern border. ${ }^{3}$ The Belarusian countryside provided an increasingly fertile ground for the slogans of the KPRP. For obvious reasons, the sentiments among the leaders of the Belarusian minority in Vilnius would become subject of interest for the security authorities of the Polish state.

Andrzej Misiuk, author of the seminal work on the history of the State Police in the Second Polish Republic, determined ${ }^{4}$ that the Political Police has been thoroughly reorganised three times during the interwar period, and its activity can be divided into the following four periods: 1919-23, 1923-24, 1924-26 and 1926-1939. ${ }^{5}$ Walery Roman's term of office as Governmental Commissioner corresponded to the second of the periods identified by A. Misiuk, which began on 26 April 1923, and ended on 27 May 1924. Władysław Sikorski (who, in April 1923, served concurrently as Prime Minister and Minister of Internal Affairs) called into being the Information Service, a body subordinate to tahe political executive. The position of Head of the Information Agency (Oddział Informacyjny) of the Department of Public Security of the Ministry of Interior was assumed by Marian Swolkień. The Information Agency consisted in the years 1923-24 of two branches, one of which comprised a number of sections, including the Belarusian section. ${ }^{6}$

At voivodeship level, the competences of provincial information divisions were assigned to district offices of the Political Police created under the district headquarters of the State Police. According to the records from June 1925, i.e. six months before the establishment of the Vilnius Voivodeship, 65 officers were employed in the $16^{\text {th }}$ District of the State Police. ${ }^{7}$ According to data from 1926, six offices of the Political Police were operating within the Vilnius district. In the

${ }^{2}$ H. Cimek, "Białorusini w ruchu rewolucyjnym w II Rzeczypospolitej”, in: Kwestia narodowościowa w Polsce $i$ we Włoszech w XX wieku. Wybrane problemy, ed. H. Cimek, Rzeszów, 2011, p. 184.

3 The Communist Party of Western Belarus was founded as an autonomous organisation within the Polish Communist Party, as a result of the merger of communist circles from Białystok, Brześć (now Brest), Grodno and Vilnius.

4 A. Misiuk, Policja Państwowa 1919-1939, Warszawa, 1996, p. 371.

${ }^{5}$ More: ibid, pp. 252-253 and further.

${ }^{6}$ The entire structure is thoroughly described by A. Misiuk, see: ibid., pp. 251-287.

7 Ibid., p. 273. 
absence of data, it is difficult to assess the size of the Vilnius office at the turn of $1923 / 24$, but we can assume that it was the largest office of the district.

The Information Agency was entrusted with gathering and analysing materials obtained from field units. The police officers resorted to various methods in their work, but it seems that in 1923-24, they focused primarily on confidential sources. As a result, the Vilnius district offices provided the Belarusian section with lots of interesting biographical information about the main figures of the Belarusian movement; surprisingly though, the reports covered mainly the years before 1919, rather than 1920-24. It should be emphasised that these reports on major Belarusian political activists not only do expand the current knowledge about the individual fate of each person in question, but also contain extremely interesting and revealing elements in the characteristics of more or less famous people. But even though the information gathered in 1924 by the Information Service constitutes a rich source of knowledge for modern historians, the effects of the agents' work failed to meet the expectations of those responsible for the security of the state at the time. As a result, this body was abolished in May 1924, to be replaced by a department of the Political Police. ${ }^{8}$ The latter's Vilnius-based employees were, for the most part, former officers of the Information Agency, who would make use of the data gathered at their former workplace. Therefore, the terms "Political Police" and "Information Agency" can be used interchangeably with regard to the presented sources.

Based on information contained in the documents issued by the Information Agency of the $16^{\text {th }}$ (Vilnius) District of the State Police, and on the comments made by their authors, we may now draw an "image of the Belarusian movement in the eyes of the Poles in Vilnius around 1923-24" and guess the attitude of the Polish administrative authorities towards the local Belarusian leaders.

Given the particular political situation prevailing in the north-eastern territories in the years $1923-24,{ }^{9}$ it is understandable why the Department of Security (Information Agency) of the Ministry of Internal Affairs in Warsaw had held, back in late 1923, an inquiry to the Governmental Commissioner for the City of

8 The rules for the organisation of the headquarters of the Political Police ( $5^{\text {th }}$ Dept. of the Gen. HQ of the PP) were announced on 1 July 1924, and the position of head of the $5^{\text {th }}$ Department was assumed by Marian Swolkień. The department was composed of two units; in addition to the information section, Swolkien was responsible for the "crime" unit, which consisted of several sections, including the "communist-subversive" section (anti-Polish demonstrations were increasingly observable in the north-eastern territories at that time) and the "Belarusian-Lithuanian" one.

9 See: Walka instytucji państwowych z białoruską działalnościq dywersyjną 1920-1925, comp. and ed. W. Śleszyński. Białystok, 2005, p. 182. This situation and its causes have been recently discussed by P. Cichoracki, Stołpce-Łowcza-Leśna 1924: II Rzeczpospolita wobec najpoważniejszych incydentów zbrojnych $w$ województwach pótnocno-wschodnich, Łomianki, 2012, p. 337. An extensive bibliography can be found there. 
Vilnius with regard to the leading Belarusian activists in Vilnius. In the archives of the Governmental Commissioner, I have found 15 reports that have been issued in response to this inquiry between December 1923 and June $1924 .{ }^{10}$

They involved several Belarusian activists, who are presented here by alphabetical order of the Polish rendition of their names, as follows: Usyevalad Bil'dzyukyevich, Klawdziy Duzh-Dushewski, Fabiyan Yaremich, Mikhail Kakhanovich, Arsyen Kanchevsky, Mikalay Krasinski, Yazep Lahinovich, Anton Luckevitch, Yazep Mamon'ka, Radaslav Astrovski [Ostrowski], Mikhail and Frantsishak Pyatkyevich, Vasil' Rahulya [Ragulya], Symon Rak-Mikhaylowski and Uladzimir Samoyla. The list is supplemented with a note on [Boris] Kletskin, a Jewish supporter of the Belarusian movement.

As we may notice, not all Vilnius-based Belarusian activists from that period have been included in the reports. ${ }^{11}$ On the other hand, some of those who were included had definitely left the city prior to $1923 .{ }^{12}$

${ }^{10}$ Lietuvos Centrinis Valstybes Archivas (LCVA), fond 51 (Urząd Wojewódzki Wileński), ap. 17, byla 6. Kleckin a Białorusini l.V 4376/24/V, lap. 1; Łuckiewicz Antoni, lap. 11-11v (Urząd Komisarza Rządu na m. Wilno, L.dz. 1419/I/24/Ag.inf, Vilnius, 7.03.1924 Do Oddziału Informacyjnego w.m. Charakterystyka Łuckiewicza; Pietkiewicz Franciszek, lap. 13. (Urząd Komisarza Rządu na m. Wilno, L.dz. 3973/I/24/Ag.inf, Vilnius, 3.06.1924. Do Oddziału Informacyjnego w.m. Pietkiewicz Franciszek. Informacje. [Podp. M. Olendzki]); Pietkiewicz Michał, lap. 14 (Urząd Komisarza Rządu na m. Wilno L.dz. 2079/I/24/Ag.inf, Vilnius, 4.04.1924. Do Oddziału Informacyjnego w.m. Pietkiewicz Michał. Informacje. [Podp. M. Olendzki, kierownik Agent. Inf.]); Ostrowski Radosław, lap. 15-15v (Charakterystyka Radosława Ostrowskiego); Samoyla Włodzimierz, lap. 16-16v (Urząd Komisarza Rządu na m. Wilno, L.dz. 2078/I/24/Ag.inf, Vilnius, 4.04.1924. Do Oddziału Informacyjnego w. m. Samoyla Włodzimierz. Opinia. [Podp. M. Olendzki, kierownik Agent. Inf.]); Bildziukiewicz Wsiewołod, lap. 18. (Urząd Komisarza Rządu na m. Wilno, L.dz. 2080/I/24/Ag.inf, Vilnius, 4.04.1924. Do Oddziału Informacyjnego w.m. Bildziukiewicz Wsiewołod. Opinia [Podp. M. Olendzki, kierownik Agent. Inf.]); Łohinowicz Józef, lap. 20-20v (Urząd Komisarza Rządu na m. Wilno, L.dz. 2077/I/24/Ag.inf, Vilnius, 4.04.1924. Do Oddziału Informacyjnego w.m. Łohinowicz Józef. Opinia. [Podp. M. Olendzki, kierownik Agent. Inf.]); Konczewski Arseniusz, lap. 22 (Urząd Komisarza Rządu na m. Wilno, L.dz. 2077/I/24/Ag.inf, Vilnius, 4.04.1924. Do Oddziału Informacyjnego w.m. Konczewski. Opinia. [Podp. M. Olendzki, kierownik Agent. Inf.]); Kochanowicz Michał, lap. 24; Jeremicz Fabjan, lap. 25-25v-26; Ragula Bazyli, lap. 27-27v-28; Duż-Duszewski Klaudiusz, lap. 29-29v; Michał Krasiński, lap. 30-31; Szymon Rak-Michajłowski, lap. 32-33.

11 According to the findings of the Police, in the summer of 1923, the District Committee of the Socialist Revolutionaries (SRs) in Vilnius was composed, besides Łuckiewicz i Łohinowicz, of: Ławrynowicz, Swietogor, Stepom, Rodziewicz, Szyło, Łapin, Drucki-Podberski, Miotła, Listopad, Budkiewicz, Eugeniusz Jużyk vel Iwżyk, Sapak-Sapaczyński, Szymański, Ejsmontt and Lidia Ustinowicz [translator's note: Polish renditions of names in italics]. The Belarusian Central School Council (with its seat in Vilnius, Wileńska 12) consisted of Trepko and Żawryd. The Council of the Society of Belarusian Schools ("Shkola") was composed - besides Rak-Michajtowski, Euckiewicz, Taraszkiewicz, Kochanowicz, Konczewski, Rev. Stankiewicz, Pietkiewicz and Łohinowicz - of: Bogdanowicz, Kotowicz, Mankiewicz, Sokołow, Gieniaszij, Budźko, Kunicki and Poczopko.

12 Between 13-25 June 1923, a bitter conflict erupted between the then Principal of the Belarusian Gymnasium and the rest of his subordinate personnel. Deputy Kakhanovich moved permanently to Baranowicze [Baranavichy]. Klawdziy Duzh-Dushewski lived and worked in Kaunas since 1921. 
The style of expression and argumentation, as well as the assessment of individual political events and facts contained in the descriptions, suggest that they have been written by several people. Some reports have been signed on behalf of the Governmental Commissioner by the Head of the Information Agency of the Governmental Commissioner's Office, M. Olendzki. Some of the reports are unsigned "appendices", which belonged to documents that have not been recovered. ${ }^{13}$

In ten cases, the information found is extensive and brings a lot of amazingly specific details (even though "specific" does not mean "ultimately confirmed") on the activities of given figures in the years between the beginning of the century and the year 1919. I believe that these notes were based on information obtained from ethnic Belarusians who, for various reasons, collaborated with Poles. After all, it is highly unlikely for the many details regarding, for instance, the internal balance of power within the Belarusian Central Military Council in 1917, to be known to anyone other than its members. I assume, moreover, that not all informants were driven solely by financial gain.

The superficiality and vagueness of the information (or even the lack of basic facts) gathered by the employees of the Political Police in Vilnius with regard to the activity of the Belarusian leaders, both during the period of the Civil Administration of the Eastern Territories ${ }^{14}$ and that of Central Lithuania, support the thesis that the Vilnius office of the Information Service took into account, in principle, only confidential sources. Apparently, the documentation drawn up by the administrative authorities in previous years was not used. Whatever the reasons were for such an approach, the gaps in the knowledge on the whereabouts of the Belarusian leaders in the years 1919-1922 prove either the low efficiency of the security service of the above-mentioned police structures, or the incompetence of its employees.

Throughout the reports, one may notice that the informants of the Polish agents willingly provided information about events from 6-7 years prior in particular, simultaneously sketching detailed psychological profiles of selected Belarusian activists. This could serve to neutralise or weaken the position of political adversaries (hence information about people that may have been significant in the past, but have long left Vilnius). Another surprising observation is that the Belarusian informants knew almost nothing about the inarguably most important of their activists, Anton Lutskyevich. ${ }^{15}$ One century later, we cannot state for sure whether this was due to some self-censorship or ignorance on the part of the informants, or to the plausible possibility that they were acting at the behest of Anton

${ }^{13}$ LCVA, fond 51, ap. 17, byla 6: Kochanowicz Michał, lap. 24; Jeremicz Fabjan, lap. 25-25v-26; Ragula Bazyli, lap. 27-27v-28; Duż-Duszewski Klaudiusz, lap. 29-29v; Michał Krasiński, lap. 30-31; Szymon Rak-Michajłowski, lap. 32-33.

${ }^{14}$ More on the Civil Administration of the Eastern Territories, see: J. Gierowska-Kałłaur, Zarzad Cywilny Ziem Wschodnich 19 lutego 1919 - 9 września 1920, Warszawa, 2003, p. 447.

15 Anton Lutskyevich (1884-1942): see fn. 45. 
Lutskyevich. ${ }^{16}$ I would like to stress that it remains a matter of conjecture whether the Belarusians collaborating with the Polish authorities indeed knew nothing of the most important facts from the years 1920-1924 (which seems unlikely), or rather that they deemed inadvisable to inform their Polish "colleagues" from the State Police about some of them.

The present article introduces a number of Belarusian names usually virtually unknown to Polish readers, which makes it necessary to employ numerous and extensive biographical footnotes. And this is where a problem arises. As a matter of fact, everything we know about these people is the collective result of the work of many authors, usually Belarusian historians. Despite their efforts, those are not full biographies. The website of the Polish Sejm currently (i.e. December 2014) features an appeal for information such as, for instance, the date and place of death of the Belarusian senator Vyachaslaw Bahdanovich and others. ${ }^{17}$ I personally believe that, at the current stage of research, we are nowhere near obtaining the definitive biographies of many of these figures; a conclusion due to numerous factors. The level of knowledge of each author with regard to the fate of the Belarusian leaders varies greatly. The informants were usually Belarusians and, as far as I know, they were Orthodox Christians, which could have made a difference in some cases. Disparities occur not only in terms of facts, but even in regard to the correct spelling of the surnames. In my biographical footnotes, I indicate the source of each information: Aleksandra Bergman (Sprawy białoruskie w II Rzeczypospolitej, Warszawa, 1984 = AB), Krystyna Gomółka (Białorusini w II Rzeczypospolitej, Gdańsk, 1992), Oleg Łatyszonek (Białoruskie formacje wojskowe 1917-1923, Białystok, $1995=$ OŁ), Andrei Charniakevich(А. Чарнякевіч, Постаці беларускага нацыьянальнага руху у Гродне 1909-1939: біяграбічны даведнік, Minsk, 2003 = ACh), Eugeniusz

${ }^{16}$ According to data from Ewidencja wybitniejszych osób pracujacych w organizacjach politycznych, społecznych, zwiazkach zawodowych, kooperatywach i organizacjach zawodowych w mieście Wilnie ("List of eminent people working in political and social organisations, trade unions, cooperatives and professional organisations in the city of Vilnius"), during the election campaign for the First Term Sejm, Radaslaw Astrowski had established, via Yazep Mitkyevich, confidential contact with Anton Lutskyevich, and secretly supported the Block of National Minorites, although officially he maintained contact with "Zialony Dub", allegedly acting as an opponent of the Belarusian National Committee based in Vilnius. Extensive information on Radaslaw Astrowski from the year 1926 - an extract from the aforementioned Ewidencja - is kept at the Archives of Modern Records (hereinafter: AAN), MWRiOP, no. 1062, pp. 375-382.

17 Vyachaslaw Bahdanovich, Вячаслаў Васілевіч Багдановіч, Wiaczesław Bohdanowicz (18781941?): activist associated with the Orthodox Church, a graduate of the Kiev Theological Academy; inspector of the Orthodox Spiritual Seminary in Vilnius since 1907, later its rector. In 1917, he was a delegate to the Holy and Great Council of the Orthodox Church in Moscow; founder of the Belarusian Orthodox Union; senator since 1922, and member of the Belarusian National Committee in Vilnius since 1920; opponent of the autocephaly of the Belarusian Orthodox Church; incarcerated at the Bereza Kartuska prison. Arrested by the NKVD in October 1939, his fate remains unknown [DM2, fn. 277]; http://pl.wikipedia.org/wiki/Wiaczes\%C5\%82aw_Bogdanowicz (access: 6 December 2014). 
Mironowicz (Białoruś, Warszawa, $1999=\mathrm{EM} 1 ; 2^{\text {nd }}$ ed.: $2007=\mathrm{EM} 2$ ). An attempt to summarise these findings was undertaken in 2006 by Dorota Michaluk ("Jestem przyjacielem Białorusinów - raporty wywiadowcze Romualda Ziemkiewicza do II Oddziału Sztabu Generalnego WP z lat 1922-1923, ed. D. Michaluk, Białoruskie Zeszyty Historyczne, vol. 25 [2006], pp. 209-258 [= DM1]) and vol. 26 [2006], pp. 236-280 [= DM2]). Many more names should be mentioned here.

There also remains the question of "copyright" (or the responsibility for false statements). Personally, I believe that the contents of the short notes that cover basic data such as major dates and political/social functions do not require bibliographical references, but Andrej Czarniakiewicz's biographical notes on the 16 figures appearing in the present study definitely do.

In spite of the widespread criticism of the internet as a (un)reliable source of information, I would like to draw the readers' attention to one, often discredited website. I wish to express here my deepest appreciation to the large group of Belarusian volunteers who attempt to bring the "flame of knowledge" to their compatriots in Belarus by creating and expanding the contents of the Belarusian Wikipedia. ${ }^{18}$ It is a well-known fact that the access to knowledge and the freedom of speech are not as broad in Belarus as they are nowadays in Poland. Hence my decision to feature in my biographical footnotes several articles that deserve a mention, especially that they usually contain references to a wide and constantly supplemented bibliography, as well as links to other interesting websites.

As I mentioned earlier, the employees of the Information Agency at the $16^{\text {th }}$ (Vilnius) District of the State Police largely relied on informants in their work. The veracity of such a source could also be the subject of long academic arguments. I myself believe that the reports that were based on such accounts credibly reflect the state of knowledge of their authors. The information found there allows the reconstruction of the decision-making processes during that period.

The contents of the agreement signed on 17 March 1923 in Minsk (hereinafter the Minsk Agreement) between the representatives of the Belarusian Socialist Revolutionaries, Social Democrats and Socialist Federalists residing in Lithuania, and the plenipotentiaries of the Belarussian SSR, were known to the Polish Political Police relatively early. ${ }^{19}$ The agreement was subject to detailed evaluation at the

18 According to my knowledge, the Belarusian articles published on Wikipedia are supplemented inter alia by the participants of the general course "Józef Piłsudski and the issue of Belarusian statehood" that I have taught at the University of Warsaw.

${ }^{19}$ Komenda Policji Państwowej Okręgu XVI Wileńskiego Okręgowy Urząd Policji Politycznej L.dz 8723/24/V Ściśle tajne. Zarys ruchu białoruskiego od czasów jego powstania aż po dzień deklaracji mińskiej z 1.03.1924. Zawiera obszerne fragmenty układu. Lietuvos Centrinis Valstybas Archivas (Vilnius), fond 51, ap. 17, lap. 5, k. 1-85. I have found the same document at the Archives of Modern Records in Warsaw (Zespół Policji Politycznej z Wilna, no. 7, k. 2-93). Cited 
District Office of the Political Police at the Headquarters of the $16^{\text {th }}$ (Vilnius) District of the State Police, established in June 1924. The analysis, signed by the head of this unit, M. Olendzki, depicted the future of Lithuanian-Belarusian relations in an ominous light for the latter.

The Minsk Agreement was concluded between Zmitsyer Zhylunovich ${ }^{20}$ and Usyevalad Ihnatovsky, ${ }^{21}$ plenipotentiaries of the Belarussian Soviet Socialist Republic, and Alyaksandr Halavinski, ${ }^{22}$ Alyaksandr Val'kovich ${ }^{23}$ and Halubyntsaw, acting on behalf of the Belarusian Socialist Revolutionary Party, the Belarusian Social Democratic Party and the Belarusian Socialist Federalist Party. The agreement, a copy of which was brought to the Polish authorities, was of course secret. ${ }^{24}$

hereafter as: Zarys ruchu białoruskiego ("Outline of the Belarusian movement"). I am considering releasing the entirety of this extensive text in print.

20 Zmitsyer Zhylunovich, Зміцер Хведаравіч Жылуновіч, Zmicier [Dymitr] Żyłunowicz; pseudonym Tsishka Hartny, Цішка Гартны (1887-1937): employee of the Belarusian Committee of Refugees (1916); activist of the Belarusian Socialist Hramada (1917); participant, secretary, and chairman of the First All-Belarusian Congress in Minsk; Prime Minister of the Byelorussian Soviet Socialist Republic in 1919. Editor of "Sovetskaya Belorussiya" since 1920. In 1920, he became a member of the Central Executive Committee of the Belarussian Soviet Socialist Republic (collegial head of state). He sought to establish cooperation with the left wing of the Belarusian National Republic (BNR), including the Belarusian Socialist Revolutionary Party. From 1927 to 1929 , he was a deputy member of the Central Committee of the Communist Party (bolsheviks) of Belarus and the All-Union Communist Party (bolsheviks). In 1934-36, he was an employee of the Institute of History of the Belarusian Academy of Sciences. In 1936, he was arrested on charges of belonging to "counter-revolutionary organisations", then murdered in prison by the NKVD [EM2, p. 298; DM2, fn. 243]; http://pl.wikipedia.org/wiki/Zmicier_\%C5\%BBy\%C5\%82unowicz (access: 6 December 2014).

${ }^{21}$ Usyevalad Ihnatovsky, Усевалад Макаравіч Ігнатоўскі, Wsiewołod Ignatowski (1881-1931): Belarusian national activist, member of the Hramada and $\mathrm{CP}(\mathrm{b}) \mathrm{B}$, Commissar of Education of the BSSR, Director at the Institute of Belarusian Culture and the first president of the Academy of Sciences of the Byelorussian SSR. He supported the creation of the Byelorussian Soviet Socialist Republic both in 1919 and in 1920, seeing its existence as a chance for an at least partial achievement of their independence goals. He was a member of the Russian Communist Party (bolsheviks) and the $\mathrm{CP}(\mathrm{b}) \mathrm{B}$; one year later, he was appointed Commissar of Education. In 1922-30, he was a member of the Central Executive Committee of the Byelorussian Soviet Socialist Republic. From 1924 to 1926, he headed the Department for Agitation and Propaganda of the Central Committee of the CP(b)B. In the 1920s, together with Alyaksandr Charvyakow and Zmitsyer Zhylunovich, he was involved in the efforts to attract activists of the Belarusian national movement back from emigration; http://pl.wikipedia.org/wiki/Usiewa\%C5\%82ad_Ihnatouski (access: 6 December 2014).

22 Alyaksandr Halavinski, Аляксандр Кузміч Галавінскі, Aleksander Gołowiński (1886-?): member of the governmental delegation of the BNR appointed on 21 March 1919 for the Peace Conference in Paris; in the Byelorussian SSR since 1927, member of the Institute of Belarusian Culture and researcher at the Belarusian Academy of Sciences [OE; ACh, pp. 65-66].

23 Alyaksandr Val'kovich, Аляксандр Іванавіч Вальковіч, Alaksandr Walkowicz (1892-1937): member of the Belarusian Socialist Revolutionary Party, Minister of Finance of the Belarusian National Republic; sentenced by the Soviet authorities to death by firing squad.

24 Rozdział XXII: "Porozumienie się przedstawicieli rządu Łastowskiego i lewicowych ugrupowań białoruskich z sowietami. Umowa mińska”, in: Zarys ruchu białoruskiego. 
Both parties of this agreement wished to keep the Lithuanian authorities in the dark about the existence of the document, so that the latter would "hope that we will soon liberate Belarus and Vilnius and merge them with Lithuania". It was also predicted that in the future, the Soviets would demand the dissolution of Vatslav Lastovsky's cabinet. ${ }^{25}$ "We shall request the removal and expulsion of Lastovsky's government from the territory of Lithuania". "In such a case, we may have to terminate our official presence in Lithuania, but this will keep us free from any suspicion about the existence of that agreement" ${ }^{26}$

The confidentiality of the Minsk Agreement was meant, among others, to secure the further financing by Lithuania of the Belarusian battalion serving in its army. Given that the signatories of the agreement excluded the possibility of Vatslav Lastovsky remaining Prime Minister, his figure would be used for some time to mislead the Lithuanians. ${ }^{27}$ The documents found also touched on the issue of the cadre of the Belarusian unit, as the Soviets advocated replacing Lieutenant Razumovich - a "man of old Russian traditions" - with "someone more appropriate".

The interference of the signatories of the Minsk Agreement with the staffing of the Belarusian National Republic ${ }^{28}$ extended even further. Among the proposed

25 Vatslav Lastovsky, Вацлаў Юстынавіч Ластоўскі, Wacław Łastowski (1883-1938): Belarusian journalist and politician, literary scholar and critic, historian; member of the Hramada (1906-08), Belarusian Council in Vilnius (1918-19), and Council of the BNR since April 1918; representative of the BNR at the Lithuanian Taryba; member of the Belarusian Socialist Revolutionary Party since 1919; Prime Minister of the Belarusian National Republic in 1919-23 (since 13 December 1919); later employed at the Ministry of Belarusian Affairs in Kaunas; in the BSRR since 1927; director of the Belarusian State Museum and head of the Department of Ethnography at the Institute of Belarusian Culture (1927-29); fired (1929), then arrested (1930) and deported to Saratov, where he worked at the Department of Manuscripts of the local university; arrested again in 1938 and executed [ACh, pp. 151-152; DM1, fn. 96]; http://pl.wikipedia.org/wiki/ Wac\%C5\%82au_\%C5\%81astouski (access: 6 December 2014).

${ }^{26}$ Zarys ruchu białoruskiego.

27 "The existing Belarusian battalion will someday be ours; it should be maintained by the Lithuanians, and our task is to turn these soldiers into real Belarusians". "The money for this purpose should, and will be given to us from Minsk in an amount required by the circumstances and as decided by the Commissariat of Finance together with the Central Committee of the Communist Party of Belarus", ibid.

${ }^{28}$ Belarusian National Republic (Беларуская Народная Рэспубліка, Byelaruskaya Narodnaya Respublika): its foundation was announced on 9 March 1918 by the Executive Committee of the First All-Belarusian Congress in Minsk, during the temporary occupation of the central part of Belarusian territory by the German army. After stormy deliberations, an illusory "independence" was announced - by the majority of one vote - on 25 March 1918. In the absence of widespread international recognition and the lack of a national army, treasury or administration, and given its inability to exercise control over the postulated territory, the Belarusian National Republic had no fixed borders. On 13 December 1919, the Belarusian Socialist Revolutionary Party and the Belarusian Socialist Federalist Party performed a sui generis coup. As a result, two different prime ministers would operate concurrently. The first one was the actual Prime Minister so far, Anton Lutskyevich, who summoned the Superior Rada (Council) of the BNR, headed 
candidates to replace Vatslav Lastovsky, who would ultimately be pressured to resign, were professors Latski or Zhytlowski; Solomon Lur'ye ${ }^{29}$ and Alyaksandr Tsvikyevich ${ }^{30}$ were also deemed acceptable. The message transmitted by the Soviet side was clear:

All representatives of Belarus abroad should focus on purely political matters, thus completely avoiding communist matters, and should display hostility towards the Bolsheviks. As regards Wacław Lastowski's cabinet, considered hostile towards the authorities of Soviet Belarus, it should pursue its work so far, which means this government should remain in power for now, at least in the eyes of Western Europe. When it comes to Wackaw Lastowski himself, he should not remain the leader of this government, as he does not possess the necessary education nor the adequate reputation among the diplomatic circles of Western Europe, and therefore he should be replaced with someone more appropriate. In order to do so, we must make it look like some internal misunderstandings had erupted in the government and Łastowski resigned himself. We could invite professor Lacki or Żytłowski,

by Yan (Ivan) Syerada. It is not true that Lutskyevich has resigned in February 1920. At the LCVIA, I have personally encountered documents from the summer of 1920 signed by A. Lutskyevich as Prime Minister. He was still perceived as Prime Minister in early 1921 in the writings of Polish diplomats from Paris. As for the perpetrators of the "coup", they established a new People's Rada of the BNR, headed by Pyotr Krechewski, and a new government led by Vatslav Lastovsky. When, in the autumn of 1920, the Polish-Soviet negotiations began in Minsk, Lastovsky's signed, on 11 November 1920 in Kaunas, a secret agreement with the authorities of Lithuania regarding political and economic cooperation with the aim to create, in consultation with other nations from eastern Poland (mainly Ukrainians), a united anti-Polish front; http:// pl.wikipedia.org/wiki/Bia\%C5\%82oruska_Republika_Ludowa (access: 6 December 2014); see also: D. Michaluk, Białoruska Republika Ludowa...

29 Solomon Lur'ye, Соломон Лурье, Salomon Łurje (1890-1964): historian of antiquity, literary scholar, graduate of the Saint Petersburg Imperial University (1911), member of the Mogilev Soviet of Workers' Deputies (1917), editor of the newspaper Ekho and cooperator of the BNR Government (1918), university lecturer at the universities in Petrograd (1918), Samara (1919-20), Leningrad (until 1949), doctor of historical studies (1934), doctor of philological studies (1943), university lecturer in Lviv (1953-64) [DM2, fn. 248].

30 Alyaksandr Tsvikyevich, Аляксандр Іванавіч Цвікевіч, Alaksandr Ćwikiewicz (1888-1937/1938): Belarusian historian and politician, philosopher and journalist, graduated in law from the Saint Petersburg Imperial University (1912); sworn at the court in Brest and Pruzhany, founder of the Belarusian People's Hramada in Moscow; in 1918, he was a member delegation of the Ukrainian People's Republic in Brest, in 1918-20, he focused on diplomatic activity (missions in Kyiv, Moscow and Berlin); in 1921-1923, he was appointed Foreign Minister of the BNR; in 1923, he replaced Vatslav Lastovsky as Prime Minister in the government in exile of Belarus (with its seat in Prague). He saw Minsk as the centre of political thought of Belarus; as a member of the Socialist Revolutionary Party he opted for dialogue with the Soviet Union and fighting the "Polish occupation" of Belarus; during the meeting of the leaders in exile in Berlin, he spoke in favour of ceasing the activities of the BNR authorities and recognising the statehood of the Byelorussian SSR. Following his resignation (1925) he relocated to the BSSR; we worked at the Institute of Belarusian Culture and the Institute of History of the Belarusian Academy of Sciences; arrested in 1930, he was deported to Perm. Arrested again in 1937, he was executed in Minsk [DM2, fn.: 250]. 
current minister of national minorities, to assume his position. We would not mind either doctor Eurje or Ćwikiewicz. ${ }^{31}$

All the other persons involved would remain in their positions. Lastovsky himself would assume a position allowing him to retain close contact with the Lithuanians, as it did not go unnoticed in Moscow that they valued him. It was recommended that all representatives of Belarus demonstrate a negative attitude towards communism. The long-term purpose of the agreement was no secret: "Foreign affairs should pursue their course; we should only make sure that the Western countries perceive the circumstances not as Bolshevik action, but as a national Belarusian endeavour, as if Lastovsky's government had nothing to do with the Bolsheviks and Minsk". "Otherwise we may not obtain [the recognition from?] the other countries, which we have long been striving for". 32

The agreement also included guidelines regarding the current strategy. Given the "moment of complete calm on the outside", all planned uprisings on Polish territory have been halted, as they would only "harm the cause". It was assumed that, at a favourable moment (in case of inevitable war), a handful of Belarusian partisans would infiltrate into Lithuania and support the operations of the Soviet army. As regards the government of the future independent Belarus, the agreement signed by Lastovsky in November 1919 in Minsk was to remain in power.

The good will and lack of political experience - bordering on inexplicable credulity - of a significant, and ultimately influential group of Belarusian politicians was eventually exploited by the Soviets. The assessment of the situation was rather unambiguous on the Polish side: the Belarusian political circles have been treated instrumentally in Moscow's wider strategy for Europe.

The Kremlin's potential first target were Lithuania and Poland. The lack of communication between Polish and Lithuanian authorities pushed both countries to confront their common threat on their own. The Lithuanians were also mislead by the Lithuanian-Russian treaty concluded in a moment critical for Poland, i.e. on 12 July 1920 . The conclusion of this treaty eventually proved to be fateful. At the turn of 1923-1924, Polish-Lithuanian consultations were, of course, out of the question.

The signatories of the Minsk Agreement did not conceal the fact that their long-term goal was to "reclaim Western Belarus from Poland", which required both conscientiousness and financial resources that were to be transferred in the amount of 15 thousand francs per month as a subsidy for Lastovsky's government. Several couriers were designated for that purpose: Kastus' Jezavitaw ${ }^{33}$

31 Zarys ruchu białoruskiego.

32 Ibid.

${ }^{33}$ Kanstantsyn (commonly known as Kastus') Yezavitaw, Канстанцін Барысавіч Езавітаў, Каnstancin (Kastuś) Jezawitau (1893-1946): head of the department of military formations of the Belarusian Central Military Council. In January 1918, in order to prevent an alleged annexation 
(via Daugavpils), Alyaksandr Charvyakow ${ }^{34}$ (via Riga), Mikalay Vyarshynin ${ }^{35}$ (via Prague), Noah Borowski ${ }^{36}$ (via Berlin), Mikola Shyla, Edvard Budz'ka ${ }^{37}$ and Branislaw Tarashkyevich ${ }^{38}$ (via Warsaw and Vilnius), Jakimovich, Siarhej Baran ${ }^{39}$

of the territory by the troops of Dowbor-Muśnicki, he called for the formation of a Belarusian guard, notably in Bobruysk; in February 1918, he was the Belarusian commander of the city of Minsk (the other one being Polish); he supervised the formation of Belarusian troops in October 1918; in April-May 1919, he exploited the anti-Polish sentiments of the Jewish community in Grodno; he was a representative of the BNR government in Latvia. His activity during World War II is describred more extensively by J. Grzybowski in Pogoń między Ortem Białym, Swastyka i Czerwona Gwiazdą: białoruski ruch niepodległościowy w latach 1939-1956, Warszawa, 2011; see also Dokument X, in: J. Gierowska-Kałłaur, Studia z Dziejów Rosji i Europy Srodkowo-Wschodniej, 47 (2012), pp. 208-272, http://www.sdr-ihpan.edu.pl/files/10_gierowska.pdf.

34 Alyaksandr Charvyakow, Аляксандр Рыгоравіч Чарвякоў, Aleksander Czerwiakow (1892-1937): Soviet state and party activist; 1920-1924 chairman of the Council of People's Commissars of the BSSR, member of the Central Committee of the $\mathrm{CP}(\mathrm{b}) \mathrm{B}$, committed suicide after being subject to criticism at the XVI Congress CP(b)B [DM1, fn. 88].

35 Mikalay Vyarshynin, Мікалай Вяршынін, Mikoła Wierszynin: professor, collector and archivist, chairman of the Belarusian Association in Prague; initiator of the foundation of the Belarusian Emigration Archives in Prague in 1928 (funded by the Czechoslovak Ministry of Foreign Affairs).

36 Most probably Noah Borowski (1885-1944): German-language translator and editor (e.g. Lenin works) for a number of publishing houses; employed in 1932 at Publishing Association of Foreign Workers; during this time, he translated Popov's outline of the history of the All-Union Communist Party (bolsheviks) into German (Moscow 1932), where he expressed subtle criticism and personal scepticism towards the contents in the German comments. He was fired as a consequence; in 1938, he was arrested and deported to Alma-Ata, where he died in 1944; see: http:// www.yale.edu/annals/Chase/Documents/doc20chapt4.htm (access: 1 January 2015).

${ }^{37}$ Edvard Budz'ka, Эдвард Адамавіч Будзька, Edward Budźka (1882-1958): journalist; participant of the First All-Belarusian Congress; he took part in the organisation of the Belarusian Gymnasium in Budsław in 1918, and of Belarusian studies in Lithuania and Latvia in 1921-40. During the German occupation (1941-44), he worked as a teacher in Minsk and Baranavichy; after the war, he emigrated to Germany; he died in the United States [DM1, fn. 71].

38 Branislaw Tarashkyevich, Браніслаў Адамавіч Тарашкевіч, Bronisław Taraszkiewicz (18921938): graduate of the Petrograd Imperial University (1916); lecturer at the latter's Chair of Russian Language and Slavic Studies (1916-18); one of the leaders of the Hramada since 1917, in the Belarusian Social Democratic Party since 1918. The authors of biographical notes usually omit the fact that, following the coup of 13 December 1919, he had joined the Superior Rada, which operated until mid-1920 with the support of Polish partisans of the federation. In late 1920, together with Vatslav Ivanovsky, he joined the Provisional Governing Commission of Central Lithuania, and in 1920-22 he was director responsible for Belarusian schools. Member of the First Term Sejm and delegate of the Belarusian Political Committee at talks with Józef Piłsudski and Prime Minister Antoni Ponikowski; founder of the Belarusian Peasants' and Workers' Hramada, later a member of the Communist Party of Western Belarus (since December 1925). Convicted in February 1930, then released in an exchange of prisoners with the BSSR. Arrested in the BSSR (1937), then executed [DM1, fn. 49]. http://pl.wikipedia.org/wiki/ Bronis\%C5\%82aw_Taraszkiewicz (access: 31 December 2014).

39 Syarhyey Baran, Сяргей Іосіфавіч Баран, Sergiusz Baran (1894-1937?): member of the Belarusian Social Revolutionary Party; chairman of the Belarusian National Committee in Grodno since 1919, teacher at the local Belarusian Gymnasium. Member of the First Term Sejm in 1922. Arrested in 1923 and convicted in Białystok for the organisation of illegal insurgent structures 
and Shymon Jakaviuk ${ }^{40}$ (via Grodno) or Solomon Lur'ye ${ }^{41}$ and Dryyer (via Danzig).

It appears that the Polish side, well aware of the agreement of 17 March 1923, placed emphasis on monitoring the activities of the Belarusian members of the Sejm, in response to the provisions of the Minsk Agreement, which proposed putting to use their presence in Warsaw, "given that such a convenient opportunity might never occur again".

The Belarusian deputies and senators were entrusted with:

- "preparing the ground" by organising cultural and educational circles, rallies, meetings and conferences where information about the Belarusian movement would be disseminated, especially among the youth;

- exploiting legal resources to obtain concessions for the Belarusians such as the opening of Belarusian schools (both secondary and special) and the publishing of newspapers, pamphlets and books with "contents harmful to Poland";

- submitting interpellations in order to release the imprisoned Belarusian activists, and calling for the adoption of a law on amnesty, which would automatically release those that could not be liberated in any other way.

The assassination of General Yazep Bulak-Balakhovich, brother of General Stanislaw Bulak-Balakhovich, was associatied in Polish intelligence circles with the provisions of the All-Russian Central Executive Committee (VTsIK) in Minsk from 1 July 1923, namely:

1) agitation should be intensified and extended to the entire Polish territory in order to instigate a coup;

2) agitation should be carried out in close contact with other Belarusian groups. It was recommended, for instance, that rumours of oppression of the Orthodox Church by Polish authorities be spread in towns with highly religious population;

3) terror should be used against major administrative officials;

4) military counterintelligence should be strengthened throughout the Polish territory.

in the Grodno Land. Released in 1927, he left Poland in 1928. In 1930 he began his studies at the Higher Pedagogical Institute in Minsk. Helena Głogowska devoted an article to him, see: H. Głogowska, "Los białoruskiego posła Sergiusza Baranowa[sic]", Białoruskie Zeszyty Historyczne 1995, vol. 2, pp. 146-159 [ACh, pp. 28-32; DM1, fn. 33].

${ }^{40}$ Symon Yakavyuk, Сымон Якавюк, Szymon Jakowiuk (1881-1973): telegraphist at the Białystok train station (1900-14), 1914-18 in the military, then became an employee of the Cheka in September 1918; in 1919, he was in contact with the Lithuanian Ministry of Belarusian Affairs; in 1920, he was secretary of the Belarusian National Committee in Grodno, secretary of the Congress in Prague; organiser of anti-Polish resistance units in the Grodno Land; member of the First Term Sejm; arrested in 1923 and tried alongside 44 other Belarusians in Białystok. Fled to Kaunas in December 1923 [ACh, pp. 277-281; DM1, fn. 38].

${ }^{41}$ Salomon Lur'ye: see fn. 29. 
In order to achieve these goals, the VTsIK decided to allocate funds in gold. ${ }^{42}$ The situation was considered alarming not only by the Polish government, but the Belarusians themselves too, whose sacrifice in blood was a proof of their Belarusian patriotism. In July 1923, Vyachaslaw Adamovich, chairman of the Belarusian Political Committee, ${ }^{43}$ submitted a letter to the Polish authorities, in which he asserted that the agitation performed by several members of the First Term Sejm, namely Rev. Adam Stankyevich, ${ }^{44}$ Anton Awsyanik, ${ }^{45}$ Symon Rak-

${ }^{42}$ Zarys ruchu białoruskiego.

43 Vyachaslaw Adamovich Sr., Вячаслаў Анто́навіч Адамовіч, Wiaczesław Adamowicz (18641939): Belarusian national activist; son of an Orthodox priest, Colonel of the Imperial Russian Army, in 1907-1914 editor and publisher of the newspaper Severo-Zapadnyy Telegraf in Kaunas; member of the Belarusian Socialist Hramada since 1917; participant of the First All-Belarusian Congress in Minsk, active member of the Central Military Council. In 1919-20, he worked at the Belarusian Military Commission; founder and chairman of the Greak Oak Peasants' Party ("Zyalyony Dub"), the political representation of the "green" units, i.e. anti-Soviet resistance composed of peasants and deserters, having its headquarters in Łuniniec [Luninyets]. He was proclaimed Prime Minister of the BNR on 16 November 1920 in Mazyr (Stanislaw BulakBalakhovich became commander-in-chief).

Ataman Vyachaslaw Adamovich (junior), pseudonym Dziergacz, was appointed head of the Green Oak's armed troops. The organisation cooperated with the Polish military intelligence. According to Oleg Łatyszonek, the Green Oak Peasants' Party was founded by activists of the Belarusian Political Committee in the run-up to the ideological and organisational fusion of the "green" units, which joined Bulak-Balakhovich's troops [OL, p. 214; DM2, fn. 314]. See also: Joanna Januszewska-Jurkiewicz, "Raport atamana Tymoteusza Chwiedoszczeni dotyczący działalności partyzanckiej na terenie Białorusi sowieckiej w okresie 10-29 czerwca 1921 r.”, Białoruskie Zeszyty Historyczne, 14 (2000); and the works of Nina Stużyńska: N.I. Stużinska, "Białoruski ruch antybolszewicki (1917-1925)", in: Społeczeństwo białoruskie, litewskie i polskie na ziemiach północno-wschodnich II Rzeczypospolitej w latach 1939-1941, ed. M. Giżejewska, T. Strzembosz, Warszawa, 1995, pp. 360-364.

44 Adam Stankyevich, Адам Станкевіч, Adam Stankiewicz (1892-1949): priest, graduate of the Roman Catholic Seminary in Vilnius and the Theological Academy in St. Petersburg; he received a doctorate in canon law in 1918; founder and leader of the Belarusian Christian Democracy. Member of the BNR Rada. He moved to Vilnius in 1919. Editor and publisher of "Krynitsa" (August 1919 - September 1922); teacher at the Belarusian gymnasium. In 1922-28, he was a member of the Sejm, where he represented the Bloc of National Minorities and was appointed deputy chairman of the Belarusian Parliamentary Club; in 1924-26 chairman of the Society of Belarusian Schools. Together with Rev. Vincent Hadlewski, he represented the Christian democrat/nationalist wing of the Belarusian movement, in opposition to the faction leaning in favour of the Byelorussian Soviet Socialist Republic. He directed the Belarusian Institute of Economy and Culture. In 1944, he was arrested by the NKVD and sentenced to 25 years of exile in Siberia, where he eventually died [EM2, p. 296; ACh, pp. 222-224; DM1, fn. 39; http://pl.wikipedia. org/wiki/Adam_Stankiewicz (access: 6 December 2014)].

${ }^{45}$ Anton Awsyanik, Антон Аўсянік, Antoni Owsianik (1888-1933?): graduate of the Kharkiv Polytechnic Institute, student at the Shipbuilding Department of the Saint Petersburg Polytechnic Institute. In 1918-19 head of the Belarusian Council in Kharkiv; left-wing activist in the Belarusian National Republic (BNR), in 1918-19 member of the Praesidium and Council of Elders of the BNR Rada, as well as the People's Secretariat of Belarus; one of the initiators of the creation of Belarusian troops within the Polish Army, in 1919-20 member and vice-chairman of the 
Mikhaylowski, ${ }^{46}$ Pyatro Myatla, ${ }^{47}$ and Vasil' Rahulya, ${ }^{48}$ as well as the senators Alyaksandr Ulasaw ${ }^{49}$ and Alyaksyey Nazarewski ${ }^{50}$ - all of whom he considered "agents of Minsk" - have produced a threatening situation. According to Adamovich, the deputies were "sowing misleading propaganda among the ignorant Belarusian people and turning them hostile towards the Polish State". ${ }^{1}$

It is understandable that, in the above situation, the Department of Security in Warsaw grew especially suspicious of two key activists: Anton Lutskyevich and Yazep Mamon'ka. In late 1923, an inquiry was submitted to the Governmental Commissioner for the City of Vilnius, asking for detailed information about these individuals.

provisional praesidium of the Belarusian Military Commission; in 1920 accredited representative of the BNR in the Republic of Lithuania; representative of the Belarusian national minority in the Second Republic, member of the First Term Sejm since 1922; in the 1930s, he left for the Byelorussian SSR, where he was arrested and possibly killed by order of the Soviet authorities [http://pl.wikipedia.org/wiki/Antoni_Owsianik (access: 6 December 2014); DM1, fn. 55].

46 Symon Rak-Mikhaylowski: see fn. 69.

47 Pyatro Myatla, Пятро Васільевіч Мятла, Piotr Miotła (1890-1936): in 1911-12 he attended Russian pedagogical courses in Kaunas; 1914-17 in the military; in 1917-21 he worked as a teacher. In 1922, he became a member of First Term Sejm. As organiser of the Belarusian Peasants' and Workers' Hramada, after its outlawing (1927) he was arrested and convicted, then exchanged for political prisoners from the BSSR. In 1933 he was sent to a labour camp, where he died [DM1, fn. 59].

${ }^{48}$ Vasil' Rahulya: see fn. 60.

49 Alyaksandr Ulasaw, Аляксандр Мікітавіч Уласаў, Aleksander Własow (1874-1941): landowner (Migówka estate), Belarusian political and educational activist; journalist and editor; chairman of the Belarusian National Committee in Warsaw and of the Society of Belarusian Schools; member of the First Term Senate. On 16 October 1939 he was arrested by the NKVD; imprisoned in Vileyka and Molodechno; on 29 November 1940, he was sentenced to 5 years in labour camp; on 11 March 1941, he died in Novosibirsk [ACh, pp. 236-237; https://www.senat.edu.pl/senat/ senatorowie-1922-1939/senatorowie-ii-rp/senator/aleksander-wlasow (access: 30 December 2014).

50 Alyaksyey Nazarewski, Аляксей Васільевіч Назарэўскі, Aleksy Nazarewski (1881-after 1940): in 1902-07 employee of the Post and Telegraph Office in Minsk; in 1915-18 organiser of support for refugees in Moscow; member of the First Term Senate (1922-1928); employee of the town hall in Baranowicze, arrested in 1940 by the NKVD; https://www.senat.edu.pl/senat/senatorowie-1922-1939/senatorowie-ii-rp/senator/aleksy-nazarewski (access: 30 December 2014); DM1, fn. 60 .

51 "Do their deeds meet with any counteraction?", asks Adamovich, "With a heavy heart, it must be said", he answers himself, "that they meet with none: not even one newspaper would attempt to expose the activities of these members of the Sejm in Warsaw, who should rather be called agents of Minsk [...] Deputies, who exploit their functional immunity to openly act against Poland, promoting the ideas of the Communist Party (at a rally in Prozoroki in the Dzisna area, deputy Stankiewicz announced, for instance, that soon autonomy will be proclaimed in Belarus, Eastern and Western Belarus will be merged, and the landlords will see their land confiscated) [...] It is necessary to unite all Belarusian groups, parties and organisations favourable to Poland in joint action against the Bolsheviks"; Zarys ruchu białoruskiego 
The report from March 1924 on Anton Lutskyevich ${ }^{52}$ is concluded with a meaningful remark: "It is beyond doubt that Lutskyevich is the most prominent Belarusian activist in Vilnius". Unfortunately, the contents of this biographical note differ significantly from their counterparts, and it should be emphasised that this fact raises several research questions. The information found in this report is of a rather gossipy nature, and it seems that its author had no idea that he was writing about pillar of the Hramada from 1903.

One emphasised fact was that the relatives of this lower-class nobleman from the Lithuanian Šiauliai [Szawle] area did not consider themselves Belarusians, and they even spoke Polish at home. ${ }^{53}$ Lutskyevich himself, during his studies in both St. Petersburg and Derpt, would consider himself a Pole. Contrary to well-known facts, the first symptom of political activity recorded by the agents of the Information Service was apparently his participation in the establishment of the anti-German Kaunas-Vilnius Citizens' Committee, an idea that was reportedly halted by internal Polish-Lithuanian conflicts. The next step in Lutskyevich's social activity was his participation in the Confederation of the Grand Duchy of Lithuania, followed by work in the field of education and in the Belarusian War Victims' Relief Association.

According to Lutskyevich's description found there, his consistent political stance, aimed at the creation of a joint Belarusian and Lithuanian state, came into collision with the German policies. ${ }^{54}$ According to the report of the Information Agency from 1924, the restoration of the Lithuanian-Belarusian state would constitute an obstacle to the plans of the Germans, who originally intended to create an ethnic Lithuania with the addition of the Vilnius and Hrodna areas. Only the recent developments

52 Anton Lutskyevich, Антон Іванавіч Луцкевіч, Antoni Łuckiewicz (1884-1942?): he graduated from the Faculty of Law at the University of Derpt (now Tartu) in 1902; in 1903, he was co-founded the Belarusian Revolutionary Hramada; active Freemason, initiator of the Confederation of the Grand Duchy of Lithuania, member of the Government of the BNR since March 1918, Prime Minister of the BNR since October 1918 (he remained in this position after the coup of 13 December 1919), member of the Superior Rada since February 1920. He still signed as Prime Minister of the BNR in July 1920; in 1921, he was formally chairman of the Belarusian National Committee in Vilnius. He directed the Ivan Lutskyevich Belarusian Museum in Vilnius. Arrested in 1927 on charges of cooperation with the Belarusian social-democratic circles. Following his release, he worked at the Belarusian Gymnasium in Vilnius (fired in 1931). In 193339, the publication of his articles was forbidden in the Republic of Poland. Arrested for interrogation by the NKVD in September 1939. The circumstances of his death remain unknown. [EM2, p. 292; ACh, pp. 156-158; DM1, fn. 15]. See also: http://pl.wikipedia.org/wiki/ Anton_\%C5\%81uckiewicz (access: 06 December 2014).

${ }^{53}$ Both Lutskyevich brothers, Anton and Ivan, maintained correspondence in elegant Polish with their mother. Portions of this correspondence can be found in the archives related to the Belarusian Museum (from 2012) at the LCVIA in Vilnius.

${ }^{54}$ Cf. J. Gierowska-Kałłaur, "Kwestia dostępu odradzającego się państwa polskiego do Morza Bałtyckiego a interesy Niemiec", in: Między historia polityczna a historiq społeczną. Księga jubileuszowa ofiarowana profesorowi Andrzejowi Skrzypkowi w siedemdziesięciolecie urodzin, ed. J. Gołota, Pułtusk-Olsztyn-Ostrołęka-Warszawa, 2014, pp. 64-81. 
on the front lines and the revolution in Germany would finally force them in 1918 to pare down their original plans. Meanwhile, Anton and Ivan had already been passionately speaking out against the German occupiers during a socialist meeting in Vilnius in 1917. Anton Lutskyevich eventually responded to the summoning of the Lithuanian Congress with the organisation of the Belarusian Congress in Vilnius, which saw the establishment of the Belarusian Rada on 25 February 1918.

The author of the study also suggested the existence of a German-Bolshevik agreement that had led to the "pacification" of the Rada of the Belarusian People's Republic (other designation of the Belarusian National Republic), ${ }^{55}$ seating in Minsk at the time. He also expressed his belief that the lack of success of the Rada in Minsk and the changes in the military and political situation in Europe had eventually persuaded the Belarusians to direct their hopes towards Lithuania. The politicians from the Belarusian National Republic simply accepted six seats in the Taryba, ${ }^{56}$ as well as the office of Minister for Belarusian Affairs, without even concluding any agreement with the Lithuanian government.

The years 1919-1920 are covered in Lutskyevich's biographical note in a surprisingly unprofessional manner. The report notably fails to even mention the circumstances of the coup from 13 December 1919, a pivotal moment for Belarus, which resulted - from a formal point of view - in a duality of power. ${ }^{57}$

On the other hand, the circumstances of the revision conducted on 1 November 1920 at Anton Lutskyevich's residence on the orders of the $2^{\text {nd }}$ Division of the Military Command of Central Lithuania have been described in detail. The authorities confiscated his manuscripts and the brochure The Polish occupation of Belarus, available in bookshops until 1 November 1920 and purportedly written by him even before the creation of Central Lithuania.

55 See: D. Michaluk, Białoruska Republika Ludowa 1918-1920. U podstaw białoruskiej państwowości, Torun, 2010, p. 597.

56 Sources indicate that, unlike the general meetings attended by Belarusians and Jews, the deliberations on more important matters in the Taryba took place without the participation of "allogenes". This situation reportedly prompted the Belarusians to leave the Taryba in protest.

57 The author of Zarys ruchu białoruskiego describes these events in the following way: "A month later, on 12 December 1919, the Rada had convened again [...] Unable to reach an agreement at the plenary session, the conciliatory faction of the Rada suggested the formation of a directorate or superior council, composed of just a few members. [...] The SRs, who were a minority, condemned this project firmly, after which the Rada closed its session. [...] On the second day, i.e. 13 December [1919], the SRs and their backers (the Socialist Federalists) gathered in a number of 50 people in the premises of the Rada and, having not allowed their opponents inside, they declared themselves a fully functional entity by excluding the conciliatory minority ( 37 people). [...] This Rada [in its new composition] adopted a resolution in protest of the 'Polish occupation' of Belarus, confirmed the act of independence of the Belarusian Republic, and chose a new praesidium. [...] Krechewski and Lastovsky were appointed, respectively, President and Prime Minister of the Rada" (p. 53 of the text). D. Michaluk (Białoruska Republika Ludowa 1918-1920. U podstaw białoruskiej państwowości, Toruń, 2010) suggests a different timeline of those events. 
This fact raises new research questions regarding Anton Lutskyevich, who, according to the information gathered by the $2^{\text {nd }}$ Division, had been receiving support from the Belvedere until July 1920 (via the Superior Rada), which he would also share with BNR politicians in Kaunas.

In exchange for vowing to remain in Vilnius, Lutskyevich was reportedly granted freedom of action, which allowed him to belong to all Belarusian institutions, to maintain foreign contacts, to organise - to quote the report - the structures of a "Belarusian secret agency", and to exercise "supervision over all activists in Vilnius". According to the findings, he was the main instigator of the boycott of elections to the Vilnius Sejm and he consciously refused to run in the elections to its counterpart in Warsaw. By staying in the background, he remained with hands untied, and suffered no consequences for his militant articles, the responsibility for which was shouldered by the editors of the newspapers Yazep Lahinovich (more about him later) and Mikola Shyla.

The interest of the Polish security service in Yazep Mamon'ka ${ }^{58}$ (residing in Prague since 1923) also seemed reasonable. Back in November 1919, acting together with Paluta Badunova - on behalf of the Belarusian Social Revolutionary Party, he had signed in Smolensk an agreement with the Bolsheviks. As a result, on 13 December 1919, he stood up against the policies of Prime Minister Anton Lutskyevich, who sought to establish a Belarusian state in consultation with Poland. According to the findings, Mamon'ka coordinated the coup in the BNR Rada that consequently led to the establishment of a rival entity, which remained in strict opposition to the political line of the BNR so far, i.e. that pursued by the Superior Rada.

The findings on Yazep Mamon'ka gathered during the Central Lithuania period were used in the report prepared in December 1923 at the special request of the Ministry of Internal Affairs. It is worth noting that these findings differ in detail and accuracy from the information provided so far in the biographical footnotes.

Mamon'ka was born into a peasant family from the Slutsk area, and received education at the local town school. A telegraphist by trade, he was appointed in 1903 to the engineer company of the fortress in Kaunas. There he joined a powerful Socialist Revolutionary organisation. According to Political Police, the Kaunas Socialist Revolutionary organisation served as a transfer point for Russian SRs fleeing abroad. They also obtained their weapons, explosives and literature there. The young Mamon'ka reportedly belonged to the terrorist faction of the party

58 Yazep Mamon'ka, Язэп Аляксеевіч Мамонька, Józef Mamońko (1889-1937): political activist, member of the Russian SRs in 1907-1917, and of the Belarusian Socialist Revolutionary Party in 1918-24. Member of the Praesidium of the BNR since 1919. In 1920, he was arrested and sent to Kaunas. In 1921 and 1925, he participated in the Prague Conference. Arrested in Minsk in 1928, and executed in exile in 1937. [DM1, fn. 93]; https://www.google.pl/?gws_rd=ssl\#q=j\%C3\%B3zef+mamo\%C5\%84ko (access: 6 December 2014). 
already back then. He enjoyed the respect of the party leaders, as "his revolutionary temperament was supported by a strong character, personal courage, innate cunning and clever orientation". "They entrusted him with risky matters and he never betrayed the trust they placed in him".

The end of Mamon'ka's military service coincided with the end of the revolution. In 1906, Mamon'ka returned to the Slutsk region where, by going from village to village for several years, he created a local organisation of Socialist Revolutionaries, which existed until World War I. The lack of information about any "Siberian episode" in his life confirms the legitimacy of Oleg Łatyszonek's doubts regarding Mamon'ka's alleged exile to Siberia.

At the outbreak of war, Mamon'ka was again called up for military service in engineer formations and - according to the findings of the Political Police - he engaged once again in cooperation with extreme left-wing circles.

The outbreak of the February Revolution found him on the North-Western Front, where the fairly powerful "Belarusian Socialist Group" conducted their agitation at that time. Mamon'ka engaged in their activities, took part in the party's congress in Minsk, and even participated in the establishment of a new party statute and programme. During the period of Kerensky's dictatorship, Mamon'ka was active on the North-Western Front, where, in accordance with the directives of the Central Committee of the Belarusian Socialist Group, he sought to create the united Belarusian Corps.

The Central Committee of the Belarusian Socialist Group convened a conference in Minsk, which gathered the representatives of all Belarusian Military Councils from all fronts of the war; according to the Political Police, the meeting (held at the governor's former residence, seized under the revolutionary order) resulted in the creation of a 30-seat Belarusian Central Military Council, of which Rak-Mikhaylowski, Adamovich and Yaroshevich were appointed, respectively, chairman and vice-chairmen. One of the seats of the Central Council has been filled by the delegate of the Council of the North-Western Front, Yazep Mamon'ka.

In view of the obstacles posed by the Bolshevik government during the formation of the $1^{\text {st }}$ Belarusian Rifle Regiment (Minsk), Mamon'ka was assigned commissar of this unit, to hold talks with the Military Commissioner in Minsk, Myasnikov. ${ }^{59}$ Since the negotiations with the Bolsheviks proved unsatisfactory, the

59 Alexandr Miasnikian, also known as Myasnikov, Александр Фёдорович Мясников, Аляксандр Фёдаравіч Мяснікоў (1886-1925): Soviet communist of Armenian origin. From September 1917 to May 1918, he headed the North-Western Committee of the RCP(b). He was elected commander of the Western Front in November 1917, and as such, he was responsible for the dispersal of the First All-Belarusian Congress in Minsk. Member of the Central Committee of the $\mathrm{CP}(\mathrm{b}) \mathrm{B}$ since 1919, in 1919-1920 member of the Central Committee of the Communist Party of Lithuania and Belarus. From January to February 1919, he was a member of the Provisional Government of the Byelorussian SSR, and served in the Central Committee of the CP(b) B. In February 1919, he was elected Prime Minister of the Byelorussian SSR (Chairman of the 
Supreme Belarusian Rada has decided to convene - in spite of the prohibition from the Bolsheviks - the All-Belarusian Congress in Minsk. One important outcome of the congress was the disintegration of the Belarusian Socialist Group, as one faction joined the Bolsheviks, another opted for the Russian SRs, widely represented at the congress, and some other participants declared themselves independents. Mamon'ka sided with the "Belarusian SRs" arriving from St. Petersburg and Moscow, and founded, together with Paluta Badunova ${ }^{60}$ and Tamash Hryb ${ }^{61}$ the "Belarusian SR Party".

Central Executive Committee of the Byelorussian Soviet Socialist Republic, Deputy Chairman of the Council of People's Commissars, and Commissar for Military Affairs). He was injured in an terrorist attack in Moscow (September 1919). Later, he became Prime Minister of the Armenian SSR, President of the Transcaucasian Federative Soviet Socialist Republic (composed of Georgia, Azerbaijan and Armenia), First Secretary of the Bolshevik Party of the Transcaucasian SFSR, member of the Revolutionary Military Council of the USSR (collective leadership of the Red Army), member of the Praesidium of the Central Executive Committee of the USSR. http:// pl.wikipedia.org/wiki/Aleksandr_Miasnikian (access: 6 December 2014); [DM1, fn. 26].

60 Paluta Badunova, Палута (Пелагея) Аляксандраўна Бадунова, Pałuta Badunowa (1885-1938): Russian language teacher from the Homel region. During World War I, she established contact with left-wing circles in Petrograd. In June 1917, she joined the Central Committee of the Belarusian Socialist Hramada. As a representative of the Hramada, she was a deputy to the Petrograd Workers' and Peasants' Council. After the split, she joined the Belarusian SRs and was appointed secretary of the Central Committee of the party. She participated in the First All-Belarusian Congress in Minsk. She was a leader of the Belarusian Socialist Revolutionaries; member of the BNR government and Rada since February 1918 (she served as secretary of social welfare). She contributed to the creation of numerous schools and shelters, and co-founded the charitable society "Tsyotka" in Minsk. On 12 November 1919, she was elected Vice-President of the BNR, then arrested as a result of the coup on 13 December 1919. In April 1920, she was a member of the delegation of the Belarusian Social Revolutionary to the talks with the Russian Bolsheviks regarding political cooperation; she hoped for the transformation of the Byelorussian Soviet Socialist Republic into a national Belarusian state. Arrested by the Bolsheviks, she was released due to poor health. Having crossed the Belarusian-Polish border illegally, she settled in Vilnius in December 1922; she was, however, expelled from the territory of the Republic of Poland. She began studying at the Dragomanov Ukrainian Higher Pedagogical Institute in Prague (1923-25). Following the dissolution of Social Revolutionary Party at the congress in Minsk in October 1924, Badunova, encouraged by the effects of the Belarusisation policy, returned to the Byelorussian Soviet Socialist Republic in January 1925, and started working at the Inbielkult in Minsk. In 1930, she left for the Homel region, where she worked as a teacher. She was eventually arrested and sentenced to 10 years in labour camp; executed on 29 November 1938 in Minsk. Лебедзева B., Пуиявінамі змагання і пакутаў: Палута Бадунова, Minsk, 2004; http://pl.wikipedia.org/ wiki/Pa\%C5\%82uta_Badunowa (access: 30 December 2014).

61 Tamash Hryb, Тамаш Тамашавіч Грыб, Tomasz Hryb (1895-1938): Belarusian political activist and journalist. He was a member of the Central Executive Committee of the First All-Russian Congress of Soviets. In July 1917, he joined the Belarusian Workers' Hramada, and later became a member of its Central Committee. At the same time, he was also a member of the Russian Communist Party (bolsheviks) and participated in the October Revolution. He eventually left the RCP(b). He participated in military congresses of Belarusians in Petrograd and Vitebsk, where he was elected to the Belarusian Central Military Council. In December 1917, he participated in the deliberations of the First All-Belarusian Congress in Minsk as a member of its 
According to data found on Wikipedia - scrupulously expanded by a large group of Belarusian volunteers - Mamon'ka, along with other SRs (Paluta Badunova, Tamas Hryb, Yawsyey Trafimaw), founded the Belarusian Uprising Committee with the aim of organising an anti-Polish uprising in Belarus. Having been denounced, Mamon'ka was expelled by the Polish authorities to Kaunas. In early 1921, at the behest of Vatslav Lastovsky, Alyaksandr Tsvikyevich and Alyaksandr Halavinski [Gołowiński], he travelled to Minsk to coordinate the underground "revolutionary struggle" against the Polish authorities in the north-eastern parts of the Second Polish Republic. ${ }^{62}$

It is worth stressing that the author of the report from 1924 assumed that the conflict between the Social Revolutionary Party and the Bolsheviks during the First All-Belarusian Congress was not due to ideological differences, but to the mere desire to acquire power

Among the activists, whose characteristics I have recently discovered, are several members of the Polish Sejm. Their parliamentary activities, however, are not really the subject of my interest. ${ }^{63}$ The reports characterise four deputies: Vasil' Rahulya, Fabiyan Yaremich, Symon Rak-Mikhaylowski and Mikhail Kakhanovich.

Vasil' Rahulya (Bazyli Rahula) left a memoir, thus his biography is quite well known; ${ }^{64}$ the veracity of such a source remains, however, dubious. Notwithstanding

praesidium. In January 1918, he took part in the Third All-Russian Congress of Soviets as a delegate of the Belarusian military. He issued a protest against the dispersal of the First All-Belarusian Congress by the Bolsheviks and the division of Belarus under the Treaty of Brest. In March 1918, he joined the BNR Rada, and co-authored the constitutional charters of the BNR. Following the seizure of Belarusian territory by the German army, he was appointed secretary in the education department of the Minsk city hall. The establishment of the Belarusian Teachers' Union took place under his direction. From January to April 1919, during the Bolshevik occupation of Vilnius, he was working as a teacher. He founded and chaired the Belarusian Socialist Revolutionary Party. Arrested by the Civilian Administration of the Eastern Territories. After his release, he resided in Kaunas (1920) and in Prague (since 1922). In 1934-38, he headed the Belarusian Foreign Archive in Prague. [ACh, pp. 69-70]; http://pl.wikipedia.org/ wiki/Tamasz_Hryb (access: 6 December 2014); M. Kietliński, W. Śleszyński, Repatriacje i migracje ludności pogranicza w XX wieku. Stan badań oraz źródła do dziejów pogranicza polsko-litewsko-białoruskiego, Białystok, 2004, p. 27 [DM1, fn. 92].

${ }^{62}$ In March 1921, Mamon'ka was arrested in Minsk by the Soviet authorities and brought to Moscow. According to Wikipedia, he was deported to Kazan, yet he managed to escape to Kaunas. This allowed him to take part, in September 1921, in the First All-Belarusian Political Conference in Prague, where he firmly criticised the Soviet Belarusian authorities. He lived permanently in Czechoslovakia since late 1922. In October 1923, Badunova and himself have issued a protest against the establishment of Tsvikyevich's BNR government in Kaunas and declared it illegal; http://pl.wikipedia.org/wiki/Yazep_Mamo\%C5\%84ka (access: 6 December 2014); [DM1, fn. 93].

${ }^{63}$ For more on the activities of the Belarusian deputies during that period, see: A. Paszkiewicz, "Białoruska reprezentacja w parlamencie II Rzeczypospolitej pierwszej kadencji (1922-1927)", Przeglad Wschodni, 9 (2004), no. 3(35), pp. 551-574.

${ }^{64}$ Vasil' Rahulya, Васіль Цімафеевіч Рагуля, Bazyli Rogula [Rahula] (1879-1955): he completed secondary school in Molodechno in 1898, then graduated from the Pedagogical Institute in 
the latter, we know that he was born into a peasant family, and graduated from a Russian teachers' seminary and the Vilnius Teachers' Institute. He claimed to have been sentenced for agitation in the Vilnius region in 1905; for unknown reasons, however, he was released and immediately admitted as teacher at a folk school in Minsk, which, according to the author of the 1924 report, was a proof that Rahulya could not have been considered a political dissident by the authorities.

Drafted to the Russian army in 1914, he supposedly served in Orsha and Smolensk where, according to the cited source, he remained for several years as deputy military chinovnik. He engaged in the anti-war and anti-military agitation of 1917. He took an active part in early Bolshevik manifestations and "joined a crowd of unruly soldiers who ripped epaulettes off from officers' uniforms and allegedly participated in the mistreatment of several officers and the looting of military depots". These details are consistent with the findings posted on the website of the Polish Sejm.

According to the report on Rahulya, the Belarusian nationalist movement was strong enough in 1917 to alarm the Bolsheviks, who thus decided to pacify it. Rahulya himself allegedly offered his services to Myasnikov, who was commander-in-chief in Minsk at the time, and was "willing to take upon himself, not free of charge of course, the role of Bolshevik spy and agent provocateur". Since he had joined the Central Military Council and the Supreme Belarusian Rada, "everything these assemblies had determined was known, via Rahulya, to Myasnikov".

Vilnius in 1906; he worked as a teacher in Smorgon and Minsk. In 1906, he was arrested by the tsarist authorities for his participation in the revolutionary movement. During World War I, he fought on the Western Front; in 1917, he joined the Russian Democratic Party. At the congress of teachers of the Minsk Governorate in May 1917, he opposed the introduction of Belarusian language in teaching; also in 1917, he took part in the First All-Belarusian Congress in Minsk (pro-Russian orientation). In 1918, he was teaching again in Minsk. In 1919-1920, he belonged to the Russian United Radical-Democratic Group, an anti-Polish organisation. Called up to the Red Army in mid-1920, he left its ranks in 1921 and returned to his homeland. He was a member of the Polish Sejm since 1922, as part of the Belarusian Parliamentary Club. Together with Fabiyan Yaremich, Usyevalad Bil'dzyukyevich and Branislaw Turonak, he established a new political party in November 1925: the Belarusian Peasant Union. In December 1925, he co-founded the Belarusian Institute of Economy and Culture. Elected senator in 1928, he was soon stripped of immunity and arrested, then sentenced to two years in prison. After his release, he returned to his birthplace, the village of Aczukiewicze [Achukyevichy] in the Nowogródek area, where he lived until the outbreak of WWII. In 1939, when the western part of Belarus was seized by the Red Army, he was working at a school in Lubcz [Lubcha]. He was arrested by the NKVD on 20 June 1941, but he managed to escape from the transport at the outbreak of the Soviet-German war. During German occupation, he undertook collaboration with the Nazis. President of the Belarusian Disctrict (Gminny) Committee, then mayor of Dzyatlava. In 1944, he was appointed vice-chairman of the Belarusian Congress convened in Minsk by the Belarusian Central Rada (with the support of the German occupation authorities); on 3 July 1944, he retreated along with the German front and ended up in Germany; in 1950, he moved to the United States; see: W. Ragula, Vspaminy, NY 1957 [ACh, pp. 194-195; DM1, fn. 14; https:// www.senat.edu.pl/senat/senatorowie-1922-1939/senatorowie-ii-rp/senator/bazyli-rogula (access: 6 December 2014)]. 
His role during the All-Belarusian Congress was rather shady. Rahulya has been entrusted by Myasnikov with procuring the "signing of agreements". However, despite Rahulya's strenuous efforts, the congress would not accept these proposals, which allegedly prompted him to trigger the well-known developments by notifying Myasnikov of an "adverse" turn of events. As a result, the congress was violently dispersed. It was commonly assumed (a belief apparently familiar to the Belarusian SRs) that among Rahulya's personal "achievements" was also the dispersal of another congress by the Bolsheviks, this time in Smolensk, where over a hundred Belarusians were arrested - and several executed. The report states that despite being aware of Rahulya's true intentions, none of the Belarusian activists would protest against his candidacy to the Polish Sejm in 1921.

The author of the report thus concluded the existence of an agreement on joint cooperation against Poland between the Socialist Revolutionaries and the Bolsheviks. Rather than a Belarusian patriot, Rahulya is flatly called an agent of the Belarusian Communist Party, “and perhaps the Russian State Political Directorate too”.

Fabiyan Yaremich ${ }^{65}$ (born in 1891, referred to as "Jeremicz" in the document), another Belarusian member of the First Term Sejm, was also born into a peasant family. He has attended a folk school, telegraphist courses, and ultimately the Electrotechnical Institute in St. Petersburg (1912). During his studies at the latter, he became a member of the Social Democratic Party. Yaremich's profile was defined in 1924 in the following words:

With no innate abilities, and surrounded by superstition and poverty since childhood, the young Jeremicz would not know, of course, to assert critically the noisy street agitators. He was attracted by revolutionary ideas, and he pictured the revolution itself in the brightest possible colours. The simple rural boy with a narrow worldview, who ended up in an unfamiliar environment in the capital, far removed from rural poverty, wished to play the role of a revolutionary, even though he could not understand properly the programme of the SD party, nor the path undertaken by the Russian revolutionaries. His incomprehension of the ideas of revolution, his narrow-mindedness, his complete lack of firm principles, the moral deformity of his soul - all of this contributed to the fact that Fabian Jeremicz, having returned from St. Petersburg to Vilnius and taken up service at the post and telegraph office, where strong black-hundredist tendencies prevailed at the time,

${ }^{65}$ Fabiyan Yaremich, Фабіян Мацвеевіч Ярэміч, Fabian Jeremicz (1891-1958): graduate of the St. Petersburg Electrotechnical Institute (1912), he began his career as political and social activist in 1917; he joined the Belarusian Socialist Revolutionary Party in 1918, then the Social Democratic Party; member of the Central Council for the Vilnius and Grodno Lands since 1919. Member of the Polish Sejm, chairman of the Belarusian Peasant Union since 1926. Mayor of Boryslav during the German occupation. Arrested after WWII by the NKVD and detained in labour camps until 1956. Following his release, he settled in Vilnius [EM2, p. 289], [ACh, pp. 289-290], [DM1, fn. 46]; http://pl.wikipedia.org/wiki/Fabian_Jeremicz (access: 6 December 2014); http://bs.sejm.gov.pl/F?func=findb\&request=000002125\&find_code=SYS\&local_ base $=$ ARS10 (access: 6 December 2014). 
immediately ceased to be a member of the $\mathrm{SD},{ }^{66}$ joining instead the renowned black-hundredist association called "Union of the Archangel Michael", founded by Furyszkiewicz. [In the "Union of the Archangel Michael", Jeremicz served as choraży, and there were many witnesses in Vilnius of his active participation in the "black-hundredist demonstrations" of 1911-13.] Jeremicz became very close with Sołoniewicz, a pseudo-Belarusian, editor of Russian-language Belarusian newspapers, which obtained fairly substantial subsidies from the tsarist government. According to informants, Jeremicz began to consider himself a Belarusian at that time and attend to the "General Belarusian Association of Vilnius", founded by Sołoniewicz.

In 1917, Yaremich had allegedly broken off all contacts with the Black Hundreds and sided with the revolution. During the seizure of Vilnius by the Bolsheviks, he worked at the freight railway station in Vilnius, where he was supervisor of the military food supply. He was suspected of stealing a large quantity of sugar during the evacuation of the Bolsheviks, as well as the perfidious elimination of the only witness to this theft - the weighman - by the hands of some Polish uhlans. The uhlans, called in by Yaremich to fend off an alleged assailant, slew the innocent man on the spot.

During the period of the Civilian Administration of the Eastern Territories, Yaremich belonged to the Belarusian National Committee in Vilnius, again as a representative of the S-D, this time the Social Democracy of railway workers. $\mathrm{He}$ owed his nomination for "chairman of the Belarusian Club of the Vilnius National Committee" [sic!], ${ }^{67}$ paradoxically, to his well-known lack of assertiveness, which Anton Lutskyevich wanted to take advantage of. One peculiar thing is the report lacking information about Yaremich's undoubted activity in the Belarusian Auxiliary Police. Yaremich's later fate validates the opinion formed in 1924 about his lack of a clearly defined direction in life. ${ }^{68}$

Another deputy featured in the reports from 1924 was Symon RakMikhaylowski. ${ }^{69}$ His fate is quite well known owing to the efforts and findings by Aleksandra Bergman, later supplemented by other scholars.

66 The Social Democratic Party

${ }^{67}$ Member of the $1^{\text {st }}, 2^{\text {nd }}$ and $3^{\text {rd }}$ Term Sejm (1922-1935), he represented the Pińsk and Nowogródek constituencies. In 1922-25, he served as vice-chairman of the Belarusian Club at the parliament; http://bs.sejm.gov.pl/F?func $=$ findb\&request $=000002125 \&$ find_code $=$ SYS\&local_base $=$ ARS10 (access: 6 December 2014).

${ }^{68}$ In the 1930s, he was an osadnik (settler) in the North-Eastern Borderlands, and member of the Osadnik Association. After the outbreak of World War II, he escaped to France, where he resided until 1941. During the occupation of Belarus, he worked in the German administration of Minsk and Baryssau. Arrested in 1945 by the NKVD for his collaboration with the Third Reich, he was sent to labour camp. Following his release, he settled in Vilnius, where he died two years later; http://pl.wikipedia.org/wiki/Fabian_Jeremicz (access: 6 December 2014).

${ }^{69}$ Symon Rak-Mikhaylowski, Сымон Аляксандравіч Рак-Міхайлоўскі, Szymon Rak-Michajłowski (1885-1937): graduate of the Molodechno Teachers' Seminary (1904) and Feodosia Pedagogical Institute (1912); member of the Belarusian Socialist Hramada (since 1917), after the split in the Belarusian Social Democratic Party - member of the Belarusian Central Military Council, 
He became involved in the activities of the Russian SRs back when he was a student at the Teachers' Seminary in Molodechno, i.e. before 1904. As a teacher, he was delegated during the 1905 State Duma elections by the peasant organisations.

According to the Political Police, Symon Rak-Mikhaylowski did in no way reveal his anti-state attitude in the years 1908-1913, which clearly contradicts the findings of historians. In 1912, he graduated from the Pedagogical Institute in Feodosia (Crimea) and began to work as a teacher. ${ }^{70}$ Shortly before World War I, he made the acquaintance of Arkadz' Smolich ${ }^{71}$ and Anton Lyavitski (Yadvigin Sh.), which prompted him to join the "Belarusian Socialist Assembly". According to the findings of H. Cimek (2011), Rak-Mikhaylowski participated in the revolutions of 1905-1907 and 1917; in the years 1914-1917, he served on the front line, then resided in Minsk. He joined the Belarusian Socialist Hramada in 1917, and became a member of its Central Committee in October that year. According to the report, he served as registrar "at some military headquarters in Minsk" ${ }^{72}$

In 1917, he was appointed chairman of the Executive Committee of the Belarusian Central Military Council in Minsk, and co-organised the First AllBelarusian Congress. One extremely interesting information that can be found on the margins of Rak-Mikhaylowski's biographical note is an account of the consolidation of the Belarusian military in 1917.

the Praesidium of the First All-Belarusian Congress, and the BNR Rada; founder of the Belarusian National Committee in Vilnius, organiser of the Society of Belarusian Schools, member of the Polish Sejm, one of the leaders of the Belarusian Peasants' and Workers' Hramada, and director of the State Museum in Minsk (since 1931); arrested in 1933 on charges of collaboration with the Second Department of Polish General Staff (responsible for military intelligence) and executed. [EM2, p. 294]; [ACh, pp. 198-200]; [DM1, fn. 29]; http://pl.wikipedia.org/wiki/Szymon_Rak-Michaj\%C5\%82owski (access: 30 December 2014).

${ }^{70}$ For his most extensive biographical note so far, based on archival sources from the AAN in Warsaw, see: Cimek, Białorusini w ruchu rewolucyjnym.

71 Arkadz' Smolich, Аркадзь Антонавіч Смоліч, Arkadź Smolicz (1891-1938): geographer, cartographer and economist. He graduated from the Minsk Theological Seminary (1905) and the Nowa Aleksandria Institute of Agriculture and Forestry in Puławy, he also studied at the Kyiv Polytechnic Institute. Member of Belarusian Socialist Hramada since 1910, and after its split the Belarusian Social Democratic Party. Participant of the First All-Belarusian Congress. An ardent supporter of the establishment of the BNR. In mid-July 1919, he warned Piłsudski against the infiltration of the planned Belarusian Military Commission by Russians pretending to be ethnic Belarusians. He also served since mid-July 1919 as deputy Prime Minister in Lutskyevich's cabinet. In 1920, he was head of the Society of Belarusian Schools in Vilnius, but then relocated to Minsk in 1922. In the BSSR, he was entrusted with the role of director of the Planning and Economics Unit of the People's Committee of Rural Economy. In 1927, he became professor at the Belarusian State University and the Institute of Belarusian Culture. He suffered repression since 1930, and was executed in 1938. [ACh, pp. 215-218]; [DM1, fn. 19]; [http://pl.wikipedia. org/wiki/Arkad\%C5\%BA_Smolicz (access: 29 December 2014)].

${ }^{72} \mathrm{He}$ was a senior unteroffizier and podporuchik at the $24^{\text {th }}$ Logistic Regiment on the Western Front (according to another source, he served on the Romanian Front, where he engaged in revolutionary agitation). 
Surprisingly, owing to agitation conducted by members of the "Belarusian Socialist Group" in the Russian Army, the Belarusian nationalist movement begins to propagate rapidly among the Russian troops. Some elemental force unites all Belarusian military personnel on all fronts alike. "Belarusian Military Councils" are being promptly established in numerous brigades, squadrons, corps and armies, with the aim of uniting all Belarusian soldiers, who will then be detached from their original units and merged into one Belarusian military formation.

There is no doubt that Symon Rak-Mikhaylowski organised and participated in the Congress of the Belarusian Military Personnel of the Western Front on 18-24 October 1917, which led to the establishment of the Belarusian Central Military Council. He was appointed chairman of the Executive Committee of the Belarusian Central Military Council in Minsk in 1917. One interesting aspect is the assessment of the role that he was reportedly meant to play in the Council according to the informants of the Political Police.

He was admitted to the Central Military Council, of which he, an ordinary registrar with no military education, was elected chairman, owing to the fact that the reign of unruly soldiers had already begun in Russia; two veteran officers, i.e. W[iaczesław] Adamowicz and Jaroszewicz, were chosen as his deputies to support him in his duties. Rak-Michajłowski himself played a very modest role in the Council. He would never interfere at meetings, and willingly gave up his seat to his deputies.

Symon Rak-Mikhaylowski "ended up" as well in the civil Supreme Belarusian Rada that was being established at that time, and comprised, apart from military figures, representatives of all Belarusian political orientations existing at the time. The objective of the Supreme Belarusian Rada was to secure the formation of at least one Belarusian division. As we know, the discussions with the commander of the Western Front, General Nikolay Dukhonin, concerning the organisation of Belarusian military formations, which took place in Mogilev in October 1917, failed to meet the hopes of the Belarusians. The convening of the First All-Belarusian Congress became an urgent necessity, and Symon Rak-Mikhaylowski engaged actively in this task.

Similarly to other reports prepared from 1924, Symon Rak-Mikhaylowski's profile contains almost no information on his rather significant activity back from 1918-1920 in Grodno. Rak-Mikhaylowski was heartily involved in the foundation of public schools, became a member of the Central School Council in Minsk, and himself taught at the Belarusian Gymnasium in Grodno in 1919. He was also the founder and principal of one of the first Belarusian teachers' seminaries, established in Boruny [Baruny] in 1921.

Rak-Mikhaylowski's profile concentrates on information about his involvement in the Belarusian Military Commission, to which he had been recommended by Pavyel Alyaksyuk. His activity in the Commission was summed up briefly: "he obviously 
endorsed all requests from the SRs and fulfilled the directives of the Central Committee of the party - Tomasz Gryb and Pałuta Bodunowa in particular".

One very interesting fragment (that raises new research questions) covers Rak-Mikhaylowski's whereabouts near the end of summer of 1920: “Accompanied by the entire Belarusian Military Commission, he headed for Wołkowysk [Vawkavysk], but then separated from the rest of the Commission, and instead of going to Vilnius, he travelled to the city of Grodno that would be seized by the Bolsheviks".

The officer of the Political Police was baffled by the fact that neither Rak-Mikhaylowski, nor his friend, Arkadz' Smolich, who was also in Grodno at the time ${ }^{73}$ have been arrested by the Bolsheviks. Smolich was appointed Commissar of the Department of Agriculture, while Rak-Mikhaylowski began publishing the Belarusian newspaper Byelaruskaye Slova without any hindrances. The report states that "the publication was only banned by the Polish authorities". "Rak-Michajłowski then left for Vilnius and promptly managed to found the Belarusian Teachers' Seminary in Boruny". "When the seminary was eventually closed, he settled anew in Vilnius, where he found work at the local Belarusian Gymnasium". "He combined his seat at the Polish Sejm with his duties as member of the Belarusian Committee in Vilnius, vice-chairman of the Belarusian School Council and active participant in the works of the Belarusian Publishing Society".

Even though the author of the report could hardly be suspected of being sympathetic towards the Belarusian activist, a little later we read: "Rak-Michajłowski is definitely a man of honour, extremely careful and reasonable; he supports the idea of creating an independent Belarus within its ethnographic borders. According to our latest information, he reportedly agreed to the creation of a Soviet Socialist Republic, as part of the Union of Soviet Republics". He then concludes: "[Rak-Mikhaylowski] is a lousy politician and tends to shy away from matters when these become too harsh" ${ }^{74}$

${ }^{73}$ Rak-Mikhaylowski was also in good terms with Pashkovich (Bolshevik serving in Minsk), Kozich, Kostyevich and Lahinovich.

${ }^{74}$ After the war, Rak-Mikhaylowski relocated to Vilnius, where he chaired the Belarusian War Victims' Relief Committee, and was a member of both the Belarusian National Committee and the Belarusian Publishing Society. Although he had belonged, since 1918, to the Belarusian Social Democratic Party, during his campaign in the 1922 elections to the Sejm, he presented himself as an independent socialist. As a member of the Belarusian Parliamentary Club, he served in the following commissions: legal, of invalidity and social welfare, and of public health. On 24 July 1925, he became a member of the Belarusian Peasants' and Workers' Hramada Parliamentary Club, of which he was secretary, author of its statute, deputy chairman of the Central Committee, organiser of the Central Secretariat and supervisor of the party's publications. In 1926, he was admitted to the Communist Party of Western Belarus. Arrested in 1927, and imprisoned until 1930. In 1931, he moved to Minsk, where he assumed the position of director at the Belarusian State Museum and member of the Central Executive Committee of the Byelorussian Soviet Socialist Republic. Arrested in mid-1933, executed in 1938. Rehabilitated after the $20^{\text {th }}$ Congress of the Communist Party of the Soviet Union. See: Cimek, Białorusini w ruchu rewolucyjnym, pp. 27-28. 
Mikhail Kakhanovich ${ }^{75}$ (b. 1882) was too born into a peasant family; he studied at the Novogrudok Gymnasium and graduated from the Historical-Philosophical Faculty of the Kharkiv University. After graduation, he settled in Vilnius, where he worked as a teacher in secondary education. Similarly as Yaremich, he cooperated closely with locally renowned "Belarusians that did not recognise the Belarusian language", Solonyevich and Kovalyuk. According to people who knew Kakhanovich, he was widely known at that time as a fierce reactionary with ties to the Black Hundreds.

After the evacuation in 1915, Kakhanovich wound up in Mogilev, where "he spoke out for the first time as a Belarusian". He joined the "Mogilev Belarusian Council" and was appointed its vice-chairman. He collaborated at the same time with the official newspaper Mogilevskiye Izvestiya [mistakenly called Mohylewski Wiestnik by the author of the report].

After returning to Vilnius in 1918, he worked at the "Belarusian Council in Vilnius" and declared the establishment of a Lithuanian-Belarusian state as his objective; he was also involved in the foundation of the "First Belarusian Gymnasium", ${ }^{76}$ of which he became the first principal. According to the findings of the Political Police, he relocated to Baranowicze [Baranavichy] in 1923 as a result of a conflict with his subordinates. The author of the report indicates that Kakhanovich was forced to resign amidst accusations of working for the

${ }^{75}$ Mikhail [Mikhas'] Kakhanovich, pseudonym M.К-ć, Міхаіл Сілуянавіч Кахановіч, Michał [Michaś] Kochanowicz (1882-1934): graduate in History and Philosophy from the Kharkiv University, teacher at Vilnius gymnasiums. In 1915, he taught at the Mogilev realschule. According to EM, we served as city councillor in Mogilev. In 1917, he became the chief editor of Mogilevskiye Izvestiya; following the February Revolution, he was appointed chairman of the Belarusian National Committee in Mogilev. In 1918-19, he resided in Vilnius, where he became involved in Belarusian national and cultural organisations. He worked as a teacher, and was the first principal of the Belarusian Gymnasium in Vilnius (1919-22). He wrote articles for such newspapers as Byelaruskaya krynitsa and Byelaruskiya vyedamastsi. He was a member of the First Term Sejm. Formally non-partisan, but actually involved (according to EM) with the radical left-wing faction of the Belarusian national movement. In 1925, he resigned as member of the Sejm and relocated to the BSRS, where he worked as editor for the newspaper Sovetskaya Belorussiya and the periodical Savyetskaye budawnitstva. In August 1933, he was arrested on suspicion of spreading of Belarusian nationalism, then sentenced in January 1934 to death by firing squad (May 1934) for belonging to the non-existent organisation "Belarusian National Centre” [EM2, p. 290], [DM1, fn. 43]; http://pl.wikipedia.org/wiki/Micha\%C5\%82_Kochanowicz (access: 30 December 2014).

${ }^{76}$ The report on Kakhanovich contains some criticism of the outcomes of education at his institution: "It is fair to say that, throughout its entire existence, the gymnasium has been raising enemies of Poland and partisans of Bolshevism [...]. A certain share of the University of Prague, composed of former students of the Belarusian Gymnasium in Vilnius, belongs to the $3^{\text {rd }}$ Student Union (bolshevik). [...] Another portion of Kakhanovich's graduates have long been working in the Soviet Belarus, and a third one - in the Belarusian villages of the Eastern Borderlands, where they would spreading Bolshevik ideas and hostility towards the Polish authorities among the populace". LCVA, fond 51 (Urząd Wojewódzki Wileński), ap. 17, byla 6 . 
Bolsheviks and the Soviet government. It is possible, however, that running in the elections and becoming a member of the Legislative Sejm in Warsaw prevented him from keeping effective control over the situation at the Gymnasium. Parallel to his duties at the Belarusian Parliamentary Club, he took an active part in the works of the National Committee in Vilnius (left-wing faction), the Central School Council and the Board of the Belarusian Scientific Society.

Although officially non-partisan, he displayed, according to the officers of the State Police, exceptional amity towards the Belarusian SRs and communists. In 1924, he was a supporter of a Belarusian Soviet Republic within its ethnic borders.

Radaslav Astrovski ${ }^{77}$ (b. 1887): he was not a member of the First Term Sejm, but alike Kakhanovich, he was among the rare Belarusians to hold a university

77 Radaslaw Astrowski, Радаслаў Казіміравіч Астроўскі, Radosław Ostrowski (1887-1976): Belarusian journalist and national/social activist, politician and educator. In 1907, he was expelled from the Slutsk gymnasium for taking part in revolutionary activities. In 1908, he entered the Saint Petersburg Imperial University to study mathematics and physics. Arrested in 1911 and imprisoned in St. Petersburg and Pskov, he was then ordered by the tsarist authorities to settle in Pruhzany under police supervision. He received permission (1913) to complete his studies at the University of Derpt. Next, he worked as a teacher in Częstochowa and Minsk; during World War I, he spent some time in Russia. He became a lecturer at the Minsk Pedagogical Institute in 1915, and obtained the title of professor. Following the February Revolution, he was appointed county commissar of the Provisional Government in Sluck. In March 1917, he took part in the Conference of Belarusian Organisations and Parties. In September that year, he founded the Belarusian Gymnasium in Slutsk, where he later taught and became its first principal. He was a member of the Belarusian Socialist Hramada, and editor of the newspaper Rodny Kray. In December 1917, he participated in the First All-Belarusian Congress in Minsk, where he opted for the creation of an independent Belarusian state. He then left for Dnieper Ukraine, and joined Denikin's Volunteer Army. In November-December 1920, he took part in the Slutsk uprising. After its collapse, he escaped with the remnants of the Belarusian troops to Polish territory. $\mathrm{He}$ resumed his political activity among Belarusians living in Eastern Poland, and worked in the distribution of American supplies. For 12 years (1924-36), he served as principal of the Belarusian Gymnasium in Vilnius. In February 1924, he initiated the foundation of the pro-Polish Polish-Belarusian Society, but after its dissolution later that year, he established contact with the illegal Communist Party of Western Belarus, of which he eventually became a member in 1926. In 1925, he was appointed deputy chairman of the Belarusian Peasants' and Workers' Hramada. He was also a member of the Board of the Society of Belarusian Schools, the Belarusian Charitable Society, the Belarusian Scientific Society, and served as the director of a cooperative bank in Vilnius, which handled the subsidies that financed the Hramada. In early 1927, Astrowski was arrested and expelled towards Central Poland. The situation changed in 1928, when he returned to political activity in favour of the Belarusian population all while demonstrating a loyal attitude towards the Polish state. In 1930, he entered the Praesidium of the Central Union of Belarusian Cultural, Educational and Economic Organisations and Institutions (Tsentrosayuz). Pressured by the administrative authorities, he relocated to Łódź in 1936. In September 1941, he moved to Minsk, where he worked in the organisation of the local Belarusian administration. He was appointed head of the "Nebenbureau", but was then dismissed by Wilhelm Kube after one month. He also served as burgomaster in several cities (Bryansk, Smolensk, Mogilev). Near the end of 1943, he became chairman of the Belarusian Central Council. In February 1944, he signed a proclamation on the creation of, and mobilisation to the Belarusian National Defense. 
degree. Sources indicate that he was born in Nesvizh. The only information about Astrovski's life from before the autumn of 1920 that was available to the District Office of the Political Police in Vilnius was that, before the war, he had worked as a teacher at a gymnasium in Slutsk, and then established its Belarusian counterpart there, of which he became the principal. This school was quickly abolished by the Bolsheviks, and Astrovski arrested. An intervention by unidentified Belarusian activists prompted the Bolsheviks to release him from custody. Astrovski relocated to Minsk and became involved with the SR movement, clearly leaning toward the right wing of the party. During the German occupation, he broke off all contact with the SRs and sought, together with Alyaksyuk ${ }^{78}$ cooperation with the German authorities. New information about Astrovski is brought by the section of the report that covers the events taking place in the autumn of 1920. "When the Belarusian Political Committee, created under the Volunteer Army of General Bułak-Bałachowicz, was transformed [on 16 November 1920], following the seizure of Mazyr, into the provisional government of the Belarusian National Republic [headed by Vyachaslaw Adamovich], Ostrowski was offered the post of Minister of Education". "He would not reach Mazyr on time, however, as the Volunteer Army had to retreat, under pressure from the Bolsheviks, back to the Polish territory".

It remains a matter of conjecture whether Astrovski could not, or did not want to do so. He displayed, however, personal courage and commitment to his homeland by taking part in the Slutsk uprising. After its collapse, he ended up on Polish territory.

In November 1920, he was working in Brest at the "American Committee for Helping Children", staying away from politics. The Belarusian National Club in Vilnius repeatedly attempted to persuade Astrovski to run in the elections to the Polish Sejm, but in vain. In November 1923, Astrovski finally gave in to the consistent urgings of Rev. Stankyevich, and thus assumed, on 1 January 1924,

Two weeks before the retreat of the German troops, he organised the Second All-Belarusian Congress in Minsk; he then fled with the BCC leadership to the Reich. [EM2, p. 294]; http:// pl.wikipedia.org/wiki/Rados\%C5\%82aw_Ostrowski (access: 06 December 2014).

78 There were at least three activists by the name Alyaksyuk. We are talking here about Pavyel Alyaksyuk (1892-?), a leading representative of the pro-Polish faction of Belarusian politicians and graduate of the Faculty of Law at the St. Petersburg Imperial University, who became one the founders of the Belarusian War Victims' Relief Association in March 1915 in Vilnius; member of the Belarusian Socialist Hramada since February 1917; between March and July 1917, he served as deputy chairman of the Belarusian National Committee in Minsk; he advocated co-opting the entire "Polish Council of the Minsk Land" by the Congress Council, which was met with indignation. Together with Raman Skirmunt, he greeted the German troops entering the station in Minsk, which caused him to get expelled from the Congress Council. Member of the People's Secretariat of the BNR since July 1918; in 1919, he joined the Belarusian Central Council of the Vilnius and Grodno Lands. From August 1919 to April 1920, he supervised the Belarusian Military Commission; chairman of the Belarusian Political Committee (since September 1920). During the 1920s, he worked as a lawyer in Nowogródek and served as vice-chairman of the Nowogródek branch of the Society of Belarusian Schools. [DM1, fn. 66]. 
the position of principal at the Belarusian Gymnasium in Vilnius. His appointment was reportedly received very badly by his companions in Minsk. The reasons for their discontent can be found in the report on Astrovski issued by the Information Agency in Vilnius two years before his arrest on charges of being a member of the Hramada:

Astrovski is a man of moderate views, he endorses the idea of an "Independent Belarusian National Republic", but unlike the left-wing SRs, he wants nothing to do with the Bolsheviks. $\mathrm{He}$ is devoted entirely and exclusively to the matters of Belarusian education. He remains cautious, applies common sense to all matters, does not like quarrels and troublemakers; he is impervious to external influence and persistent in reaching his goals. He is currently one of the most prominent members of the so-called conciliatory faction, ${ }^{79}$ established by the deputies Taraszkiewicz and Jeremicz. His attitude towards Polish authorities is completely loyal.

Klawdziy Duzh-Dushewski, ${ }^{80}$ a Roman-Catholic born into an impoverished szlachta family. In 1912 he completed the Vilnius realschule, then graduated from the Petrograd Polytechnic Institute around 1917/1918. The Belarusian movement in Petrograd was headed at that time by professors Epimach-Shypila, Vatslav Ivanowski and others. The Belarusian publishing enterprise "Zahlyanye sonce i w nashe vakontse" was financed by Princess Mahdalyena Radzivil. Klawdziy Duzh-Dushewski belonged - together with Branislaw Tarashkyevich, Mikola Shyla, Pavyel Alyaksyuk (well-known supporter of the pro-Polish orientation) and others - to two Belarusian milieus: academic and cultural/educational.

In 1919, he arrived in Vilnius as a member of the Socialist Revolutionary Party and took part in the Congress of the Vilnius and Grodno Lands (referred to, by the officer of the Polish Political Police, as the "Congress of Western Belarus", convened in May 1919 "with Piłsudski's consent"). ${ }^{81} \mathrm{He}$ was elected chairman of the Congress. His standpoint during the discussions and votes was, just like Tamash Hryb's, in line with that of the Socialist Revolutionary Party. Duzh-Dushewski was elected chairman of the then-established Belarusian Central Council of the

79 The Polish-Belarusian Association was established in February 1924.

80 Klawdziy Duzh-Dushewski, Клаўдзій Сцяпанавіч Дуж-Душэўскі, Klaudiusz Duż-Duszewski (1891-1959). Author of the Belarusian flag pattern (blood-sweat-tears). Member of the Belarusian Socialist Hramada since 1917, and of the Belarusian Socialist Revolutionary Party since 1918. Member of the Belarusian National Committee in Vilnius since 1919. In that same year, he was appointed diplomatic representative of the BNR in the Baltic states; in 1921, he emigrated to Kaunas, where he worked between 1921 and 1930 in several government offices. He was arrested by both Soviet and German authorities. He survived the war, and worked as assistant professor at the Kaunas University until 1946. Later arrested again by the Soviet authorities [2 DM, fn. 146]; http://pl.wikipedia.org/wiki/Klaudiusz_Du\%C5\%BC-Duszewski (access: 6 December 2014).

81 Cf. J. Gierowska-Kałłaur [comp.], Dokument XI: Zjazd Białoruski w Wilnie 8-9 czerwca 1919. [http://www.sdr-ihpan.edu.pl/files/10_gierowska.pdf (access: 2 January 2015). 
Vilnius and Grodno Lands, but he quickly resigned from this position. During the summer, he held lectures at the Belarusian Teachers' Courses, and then he worked, since 1 September 1919, as a geography teacher at the Belarusian Gymnasium in Vilnius. Also in 1919, he became a member of the Belarusian National Committee in Vilnius and of the Belarusian Military Commission. In 1921, he moved with his wife to Kaunas, where he joined Lastovsky's cabinet. Even though he maintained ties with the SRs, he did not participate in the preparation of the uprising in the Vilnius and Grodno Lands. Sources indicate that "he did not share the standpoint of the Belarusians in Kaunas, as he was by nature a moderate person", and also that "he enjoyed popularity among Belarusian common workers, teachers and others alike, given his character and sincere devotion to the cause".

One person, whose biographical note was rather extensive and unflattering, was Mikalay Krasinski, ${ }^{82}$ son of an Opieka szlachecka officer from Vileyka; an activist of the Black Hundreds, denounced by fellow students as an Okhrana informer.

He completed his secondary education at the Vilnius Gymnasium no. 1, then studied at the Petrograd University. In his student days, he was widely suspected of being in close ties with the local Okhrana, as it did not go unnoticed that arrests and searches often occurred shortly after Krasinski's appearance in some circle or organisation. As a Belarusian, he also frequented Belarusian events, organised by the circle of Belarusian students. He was suspected of being a traitor and having denounced this circle to the Okhrana, and some students dearly regretted the trust they had shown him, as many have been deported as a result to Siberia; the Belarusian studentry unanimously blamed Krasinski for this.

As a member of the Black Hundreds ${ }^{83}$ Krasinski took part in all Russian patriotic demonstrations, for which he reportedly received financial subsidies. The students who knew Krasinski better perceived him as a man devoid of all moral principles, dubious and faithless, ready to serve everyone, as long as we would get paid for it.

He underwent a quantum change at the outbreak of the Russian Revolution. Indeed, the former blackhundredist converted to Bolshevism; he became an ardent communist, and even a commissar. The Political Police had reason to believe that Krasinski had been sent to Vilnius by the Bolshevik secret service for political purposes. These assumptions would find confirmation in the fact that both he and his sister pointedly praised the conditions of life in Soviet Russia. Upon arriving to Vilnius, Krasinski forged links to Lutskyevich, Karabach, Prakulyevich, Kraskowski, Kakhanovich and Yaremich, and joined the Belarusian National Committee in

${ }^{82}$ Mikalay Krasinski, Мікалай Фаміч Красінскі, Mikołaj Krasiński (1891-1938): in 1922-1924, he taught at the Belarusian Gymnasium in Vilnius. [DM2, fn. 278]. An extensive report about him is archived at the LCVA, fond 51 (Urząd Wojewódzki Wileński), ap. 17, byla 6, lap. 30-31.

83 The movement known as the Black Hundreds, which comprised, among others, the Union of the Russian People and the Union of the Archangel Michael. 
Vilnius. He worked as a teacher, then inspector at the Orthodox Theological Seminary.

Widely seen as an atheist and nihilist, he exploited his close ties to the rector of the seminary, Bahdanovich, to "install himself" at the Orthodox Theological Consistory on behalf of the Belarusian National Committee in Vilnius, at the behest of Anton Lutskyevich. According to the findings of the Political Police, he operated within the environment of the Orthodox clergy, where he practised Bolshevik anti-state agitation. He was active both at the Orthodox Theological Consistory and the Orthodox Theological Seminary, and only the intervention of Archbishop Theodosius forced him to resign.

Just like Bahdanovich, he openly proposed boycotting the elections to the Polish Sejm. In spite of this, he worked for the Bloc of National Minorities at the Central Electoral Committee in Vilnius.

According to the police report, Krasinski was employed at the Belarusian Gymnasium in Vilnius during a period when Trepka, widely considered a person of weak character, was the principal. Krasinski soon overshadowed Trepka, who would give in to all of his demands. ${ }^{84}$ At the time when the report was issued, Krasinski belonged to the Belarusian National Committee in Vilnius, and was a member of the Central School Council, the Board of the Belarusian Drama Workshop and the "Belarusian Citizen Assembly" ("Byelaruskaye Hramadzyanskaye Sabran'nye").

Mikalaj Krasinski's sister, Ksenya, became the subject of keen interest from Yazep Lahinovich. ${ }^{85}$ The only confirmed information available in 1924 about Yazep Lahinovich (born, according to the Political Police, in 1896) ${ }^{86}$ was that he was a Catholic and an old SR, that he had served the entire war as a private on the front line, and that he had taken part in the Slutsk uprising, after the collapse of which he ended up in Polish territory. In May 1921, he left the internment

${ }^{84}$ According to information gathered by the Political Police, the graduates of this school were offered jobs in Soviet Belarus, studied at Belarusian State University and the Belarusian State Polytechnic Institute in Minsk, as well as in Prague, and usually belonged to the "Third Student Union (bolshevik)".

85 According to the findings of H. Cimek, Lahinovich travelled in February 1936 from Copenhagen to Moscow, where he was falsely accused and imprisoned, then eventually executed in 1940 . See: Cimek, Białorusini w ruchu rewolucyjnym, p. 15; S. Zachariasz, "Józef Łohinowicz", Z Pola walki, 3 (1961), p. 212, [AB, p. 61]. According to earlier findings by Dorota Michaluk, Lahinovich was a member of the Belarusian National Committee in Vilnius in the years in 1922-23, and since December 1923, i.e. since the merger of the BRO with the CPWB, he remained in the CC of the CPWB. He was arrested by the Polish authorities for his participation in the Fifth Congress of the Comintern in Moscow and fled to the BSSR, where he was involved in the communist movement in Western Belarus. In 1936, he was arrested on charges of cooperation with the Polish political police, then sentenced to death in 1939. He died in prison in April 1940. [DM2, fn. 281].

${ }^{86}$ Urząd Komisarza Rządu na m. Wilno, L.dz. 2077/I/24/Ag.inf, Vilnius, 4.04.1924. Do Oddziału Informacyjnego w.m. Łohinowicz Józef. Opinia. [Podp. M. Olendzki, kierownik Agent. Inf.] LCVA, fond 51 (Urząd Wojewódzki Wileński), ap. 17, byla 6, lap. 20-20v. 
camp and came to Vilnius, where he engaged in Pavyel Alyaksyuk's ${ }^{87}$ organisation "Byelaruskaya natsyyanalnaya suvyaz". He was a proofreader for the Belarusian weekly "Yednasts", and worked part-time at bailiff Umyastowski's office. These details were definitely not accurate. S. Zachariasz and H. Cimek found out that Lahinovich was in fact born in 1891, so he was already 35 years old in 1924 . He operated under various names, notably as Pavyel Korchyk, son of landless Belarusian peasant Kayatan. In 1910-12, he belonged to the Belarusian Socialist Hramada. Following the October Revolution, he joined the Social Revolutionary Party. In 1922, he became one of the leaders of the Belarusian Revolutionary Organisation, which merged with the Communist Party of Western Belarus on 30 December 1923. He became thus a member of the Central Committee of the CPWB, and then (since 1924) a member of its Political Bureau. Later, he was also a member of the Central Committee of the Communist Party of Poland (1925-36; member of the Political Bureau of the CC CPP in 1925-29, deputy member in 1929-33).

None of the authors of the biographical notes ${ }^{88}$ does provide, however, several important facts from Lahinovich's life. According to information obtained by the Political Police in Vilnius, Lahinovich was employed at the time of the 1922 legislative elections as a secretary at the Belarusian Central Electoral Committee, and quickly became its de facto leader. The newly elected deputies did appreciate his commitment and hired him as an assistant secretary at the Secretariat of the Belarusian Club in Vilnius. The position of head secretary was officially held by Rev. Balyaslaw Drutski-Padbyareski, but in reality all his duties were fulfilled by J. Lahinovich, who also assumed Rodzyevich's ${ }^{89}$ editorial duties and published

87 As established by Joanna Januszewska-Jurkiewicz, the activities of the National Association during the Central Lithuania period have been impeded by the arrest of Pavyel Alyaksyuk and his exile from Vilnius. The Civil Chancellery of the Supreme Commander of Central Lithuania requested his immediate release. According to a much later report issued by the Vilnius Headquarters of the Political Police, (LCVA, f. 15, ap. 2, b. 232, k. 37: Sprawozdanie z ruchu politycznego i ekonomiczno-społecznego w Wilnie za marzec 1925 r) Alyaksyuk was involved - in connection with the activities of the Belarusian Military Commission - "in some shady financial affairs and spent some time in prison in Warsaw, to be later released on account of Bałachowicz's intervention". J. Januszewska-Jurkiewicz established that Alyaksyuk's stance was greatly influenced by his aversion towards Russia, which distinguished him from the vast majority of Belarusian activists of his time. J. Januszewska-Jurkiewicz, Dwie "krajowe" inicjatywy białoruskie na Litwie Środkowej; http://kamunikat.fontel.net/www/czasopisy/bzh/16/16kryn_januszewska.htm (access: 6 December 2014).

88 Zachariasz, Józef Łohinowicz, p. 212; Bergman, Sprawy białoruskie w II Rzeczypospolitej, Warszawa, 1984, p. 61.

${ }^{89}$ Lyeapol'd Rodzyevich, Леапольд Іванавіч Родзевіч, Leopold Rodziewicz (1895-1938): Belarusian writer and politician. Editor-in-chief of the periodicals "Nasha buduchynya", "Byelaruski zvon" (1922-23) and "Nash stsyah baĺshavik" (1925-34). Executed during Stalin’s Purge. Initially associated with futurism, his early works include the drama Bludniki (1912); later, he wrote poetry in support of the revolutionary changes introduced by the Bolsheviks, published in volumes such as Byelarus (1922); http://portalwiedzy.onet.pl/11344,,,,rodziewicz_leapold,haslo. html (access: 6 December 2014). 
articles under the pseudonym "Kumyelhan", notably in the newspaper Nasha Zhytstsyo, which saw 13 issues under his editorship between 3 March and 21 May 1923. At the same time, Lahinovich served as secretary of the Belarusian National Committee and was a member of other, less important associations.

Lahinovich lived in the very centre of Vilnius, initially leading a modest life of a confirmed bachelor. Back then, he was described as a "rather soft, yet accurate and decisive person; otherwise sullen and taciturn". A transformation occurred upon the assumption of new duties; he now had money, which motivated him to invest in fashionable clothes, frequent cafés and socialize in general. Olendzki suggests that the change in the style and quality of life resulted from his cooperation with the Soviets. I, on the other hand, get the impression that Lahinovich's behaviour was much less due to his political and financial ties, than to the fact that he had simply fallen in love with Ksenia Krasinska. The political beliefs of this lady and her brother undoubtedly influenced Lahinovich, of whom Olendzki wrote in April 1924:

He currently praises the Soviets' strategy in Minsk, and asserts that only a Soviet Belarus could grant the independence and freedom to the Belarusian people. He believes that the Borderlands are being "occupied by Poland" and that the hateful Polish authority in the Vilnius Land may be suppressed by means of an internal strife among Poles or some external conflict. An armed uprising, on the other hand, would appear infeasible; according to him, cultural and educational efforts should be undertaken instead, in order to raise awareness among the Belarusian people.

The uncovered documents of the Political Police contain little information about other Belarusian activists, and the scarce data available is either unflattering or rather entertaining.

Before the war, Usyevalad Bil'dzyukyevich ${ }^{90}$ was a corrupted railway official, and a right-wing Russian nationalist. Upon arrival in Vilnius, he began to work in the delivery of products for the army. At the same time, he made contact with Belarusian activists and joined the Belarusian Club, where he was elected senior member. Bil'dzyukyevich was a well-known gambling organiser. However, his lottery was revealed to be rigged, and thus he was forced to leave the club. He never joined another political party.

Arsyen Kanchevsky ${ }^{91}$ was the brother of a well-known Belarusian proponent of the co-operative movement (deceased in 1924). After returning from Russia

90 Urząd Komisarza Rządu na m. Wilno, L.dz. 2080/I/24/Ag.inf, Vilnius, 4.04.1924. Do Oddziału Informacyjnego w.m. r. Bildziukiewicz Wsiewołod. Opinia [Podp. M. Olendzki, kierownik Agent. Inf.] LCVA, fond 51 (Urząd Wojewódzki Wileński), ap. 17, byla 6, lap. 18.

${ }_{91}$ Arsyen Kanchevsky, Арсен Уладзіміравіч Канчэўскі, Arseniusz Konczewski (?-1931): member of the Communist Party of Western Belarus and of the Society of Belarusian Schools; Belarusian activist in the Free City of Danzig. He drowned in the Black Sea in 1931. See: H. Głogowska, 
(in 1919), he became a student at the Belarusian Gymnasium in Vilnius, but soon dropped out and began to work at the Union of Belarusian Cooperatives. He engaged in the milieu of active socialists, and was often present at their meetings. In the autumn of 1923, he was elected to the Praesidium of the Belarusian Central School Board, and entrusted with the position of secretary. According to information obtained by the Political Police, "he was a particularly close friend of the Belarusian journalist Yazep Lahinovich”.

Mikhail Pyatkyevich, Міхаіл Пяткевіч, Michał Pietkiewicz ${ }^{92}$ (b. 5 November 1885 in the village of Zanarach, Sventsyanskiy uyezd) was "a light-hearted Orthodox bachelor, conscientious and accurate in his duties, although somewhat disinclined towards work in general".

He began his education in Baruny, then studied at the Teachers' Institute in Vilnius. He was already working as a teacher in 1902, i.e. at the age of seventeen. In 1920-1921, he was teaching at one of the Belarusian folk schools in Vilnius, and in 1924 - at the Belarusian Primary School, 9 Ostrobramska Street. In November 1923, he was elected vice-chairman of the Praesidium of the School Council. Mikhail Pyatkyevich did not, however, side with the faction of Belarusian activists that defined the policies of this ethnic group. "Private conversations in this matter revealed an unfavourable attitude towards the Polish state, which he believes will never change its policies, strategy and approach towards the Belarusians". "He praises Soviet Russia instead". "He [recently?] joined a group of Belarusian activists - partisans of a Soviet Belarus".

Frantsishak Pyatkyevich, Францішак Пяткевіч, Franciszek Pietkiewicz ${ }^{93}$ was a Roman Catholic; he embarked on medical studies at the Stefan Bathory University in Vilnius. He was energetic and reportedly developed the reputation of a "passionate Belarusian". While living in Vilnius, he "remained within the spheres of influence of the most prominent Catholic Belarusians (Rev. Stankiewicz,

Białorusini na Wybrzeżu Gdańskim, Toruń 2003, p. 262. See also: List of members of the Communist Party of Poland and the Communist Party of Western Belarus. http://www.google.pl/ url? $\mathrm{sa}=\mathrm{t} \& \mathrm{rct}=\mathrm{j} \& \mathrm{q}=\& \mathrm{esrc}=\mathrm{s} \&$ source $=\mathrm{web} \& \mathrm{~cd}=5 \& \mathrm{ved}=0 \mathrm{CDUQFjAE} \& u r l=\mathrm{http} \% 3 \mathrm{~A} \% 2 \mathrm{~F} \% 2 \mathrm{Fwww}$. gabrielesimoncini.it\%2FPublications\%2FDocs\%2FList\%2520KPP.rtf\&ei=0taEVLa3OY HmywOxgYK4Dw\&usg=AFQjCNGIXAeZaKtLXMCgO2NFLSj773ejg\&bvm=bv.80642063,d.d24 (access: 6 December 2014). Urząd Komisarza Rządu na m. Wilno, L.dz. 2077/I/24/Ag. inf, Vilnius, 4.04.1924. Do Oddziału Informacyjnego w.m. Konczewski. Opinia [Podp. M. Olendzki, kierownik Agent. Inf.]. LCVA, fond 51 (Urząd Wojewódzki Wileński), ap. 17, byla 6, lap. 22.

92 Urząd Komisarza Rządu na m. Wilno, L.dz. 2079/I/24/Ag.inf, Vilnius, 4.04.1924. Do Oddziału Informacyjnego w.m. Pietkiewicz Michał. Informacje. [Podp. M. Olendzki, kierownik Agent. Inf.] LCVA, fond 51 (Urząd Wojewódzki Wileński), ap. 17, byla 6, lap. 14.

93 Urząd Komisarza Rządu na m. Wilno, L.dz. 3973/I/24/Ag.inf, Vilnius, 3.06.1924. Do Oddziału Informacyjnego w.m. Pietkiewicz Franciszek. Informacje. [Podp. M. Olendzki] LCVA, fond 51 (Urząd Wojewódzki Wileński), ap. 17, byla 6, lap. 13. 
Trepko, et al.), as he was himself of that denomination". The report continues: "He made his way into the Belarusian War Victims' Relief Committee, and was also elected to the National Committee". "He held right-wing views". "He argued that without the support of the bourgeoisie, Belarus would not obtain a healthy society and the desired power; he sided with the bourgeoisie".

In the autumn of 1923, Pyatkyevich left for Prague with his younger brother Vatslav, student of the Belarusian Gymnasium in Vilnius. In Prague, he entered the local university, joined the right-wing faction of the studentry, and obtained a scholarship for his brother and himself; he was generally considered a fascist.

Uladzimir Samoyla ${ }^{94}$ spent almost all his life in Vilnius. He was born into a wealthy family; he studied ancient Roman literature and philosophy. He was actively involved in political and social matters: he belonged to the Russian Kadet party, collaborated with a Belarusian newspaper and was a member of the Belarusian National Committee. He remained in the Kadet party until the very last moment. He especially revered Milyukov, whose portrait adorned his residence. He taught Latin at the Weller Gymnasium, from which he was expelled on charges of plotting intrigues.

In 1920, he was editor-in-chief of the Russian-language newspaper Vilenskaya Ryech, subsidised by Mejtik and Kołtynowicz. The publication proved costly and garnered little revenue, and so it was cancelled after about a hundred issues.

As secretary of the Belarusian Central Electoral Committee during the legislative election, he played a significant role within the Belarusian movement and renewed acquaintance with the activists he had met in 1917. He wrote in Russian, and his articles were translated into Belarusian by Kościewicz or Szeleszko. Uladzimir Samoyla was reportedly known for his conceit. In 1924, he found himself in dire financial straits, which, according to the author of the report, prompted him to modify his stance and resulted in the appearance of communist overtones in his articles. ${ }^{95}$

And finally, the report on the Jew Kletskin: ${ }^{96}$

The relations of Kleckin (printing house owner) with the Belarusian activists date back to the German occupation (the newspaper Homon). In the years 1920-1921, Kleckin prints

94 Uladzimir Samoyla-Sulima, Уладзімір Іванавіч Самойла, Włodzimierz Samojło (pseudonyms Chemyer, Sulima) (1878-1941): journalist, literary critic (parents: Ivan Samoyla and Awhusta Nabokaw). See: A. Bergman, "Włodzimierz Samojło-Sulima wobec kwestii białoruskiej w Polsce międzywojennej”, Przegląd Historyczny, 74 (1983), no. 4, pp. 653-676.

95 Urząd Komisarza Rządu na m. Wilno, L.dz. 2078/I/24/Ag.inf, Vilnius, 4.04.1924. Do Oddziału Informacyjnego w.m. Samojło Włodzimierz. Opinia. [Podp. M. Olendzki, kierownik Agent. Inf.] lap. LCVA, fond 51 (Urząd Wojewódzki Wileński), ap. 17, byla 6, lap. 16-16v.

96 Urząd Komisarza Rządu na m. Vilnius. Agentura Informacyjna L.dz 4434/I/24, Vilnius, 14.06.1924. Tajne Raport M. Olendzkiego, Kierownika Agentury LCVA, fond 51 (Urząd Wojewódzki Wileński), ap. 17, byla 6 , lap. 1 . 
Belarusian books and manuals, issued by the Belarusian Publishing Society. In 1922, an agreement is concluded between Kleckin and [Rak]-Michajłowski as representative of the Belarusian Publishing Society; Kleckin prints the books at its own expense in exchange for a percentage of sales profits. The books printed by Kleckin were partly sent to Belarus, as there was little demand for them in Poland. In Soviet Belarus, on the other hand, the demand is considerable. [...] The literature printed in Minsk is sent to Poland via Kleckin. ${ }^{97}$

The officer of the Polish political police believed that the main reason for Kletskin's close ties with the Belarusians was the fact that Kleckin was reportedly a relative of Lutskyevich's spouse.

But regardless of their source, it is clear that Kletskin, who owned - according to the Information Agency - one printing house in Vilnius and another in Minsk, was a liaison between the Belarusian Committee in Vilnius and the communists in Minsk. The Polish intelligence officer described the situation briefly: "Kleckin is forced to maintain good relations with Soviet Belarus to protect his possessions there".

It is difficult to comment on previously unknown biographical information contained in police reports, as they still need to be verified in the course of further queries, which may take several years. I believe that the current state of biographical data with regard to Belarusian activists, even the major ones, cannot be considered in any way final. The scarce information showcased in this presentation sheds a new light on the motivations and roles of some activists, which we often know only from their own diaries written in exile (Rahulya).

Faithful to its name, the Information Agency focused, at the turn of 1923 and 1924, solely on the gathering, analysis and assessment of information. There is no reason to suspect this organisation of exerting any influence in its area of operation. One might also notice the officers' lack of elementary knowledge concerning the events of 1919-20, as well as the immense sense of threat to their country after March 1923.

We may, however, attempt to characterise the attitude of the Vilnius-based officers of the Polish security service towards the different Belarusian activists in 1924. It was certainly not as hostile as previously assumed in the literature. Without judging whether this is the result of the incompetence of the Polish security officers, a consequence of some poor organisation of their work, or just their "human" kindness towards the Belarusian movement, I notice in these reports a great deal of empathy for individual Belarusian activists.

The most interesting aspect, however, is the microscale image of the milieu of Belarusian activists emerging from the 15 reports discussed here. These people differed not only by their age, origin and life path; according to the findings of the $\mathrm{PP}$ in Vilnius, their activities were dictated by wildly divergent motives. 
The eldest among them were Samoyla (b. 1878), Rahulya (b. 1879), Krasinski (b. 1880) and Kakhanovich (b. 1882). Despite the significant differences of origin (Samoyla and Krasinski were representatives of the local elite), none of them was a supporter of the establishment of an independent and sovereign Belarusian state. Each one of them attempted to plan, in the most comfortable manner possible, their own career. The teachers Rahulya, Krasinski and Kakhanovich consistently sided with the Soviet system, and Samoyla joined them later, seemingly for purely pragmatic reasons.

The younger generation was represented by Lutskyevich (b. 1884) and Duzh-Dushewski (b. 1891) from petty noble families, as well as the teachers Rak-Mikhaylowski (b. 1885) and Astrovski (b. 1887). All of them had completed tertiary education, all were held with esteem by the PP officers for their ideological commitment.

Their age group also comprised two activists from peasant families, with incomparably lower professional qualifications, i.e. Mamon'ka (b. 1889) and Yaremich (b. 1991). For the former, his military service in Kaunas in 1905 was a one-ofa-kind "academy of terrorism" supervised by the Russian SRs. The latter found himself initially under the influence of the Black Hundreds, a fact that influenced his "career" in spite of his radical reorientation in favour of Bolshevism when his "tutors" had disappeared from the political scene.

\section{Translated by Jakub Perliński}

\section{The biographies of leading Belarusian activists in the light of information gathered by the Polish Governmental Commissioner for the City of Vilnius in 1924 Abstract}

In response to the complicated situation in the north-eastern territories in 1923-1924, the Department of Security (Information Agency) of the Ministry of Foreign Affairs in Warsaw decided to address in the autumn of 1923 an inquiry to their governmental commissioner about the leading Belarusian activists in the Vilnius Region. In the archives of the commissioner for the city of Vilnius, the author of the present study has found reports on fifteen Belarusian activists from the area and beyond: Usyevalad Bil'dzyukyevich, Klawdziy Duzh-Dushewski, Fabiyan Yaremich, Mikhail Kakhanovich, Arsyen Kanchevsky, Mikalay Krasinski, Yazep Lahinovich, Anton Luckevitch, Yazep Mamon'ka, Radaslav Astrovski, Mikhail and Frantsishak Pyatkyevich, Vasil' Rahulya, Symon Rak-Mikhaylowski and Uladzimir Samoyla. The study is supplemented with a note on Boris Kletskin, a Jew who supported the Belarusian movement in Vilnius.

However, the informants of the political police would avoid talking about current events, shedding instead new light on the developments from the early $20^{\text {th }}$ century, with special emphasis on personal data from the period of the First All-Belarusian Congress (a congress of Belarusian political organisations and groups held in Minsk in December 1917). This information is crucial for other reasons too, since it allows us to put forward the thesis that some of the Belarusian leaders (mainly Mamon'ka) had deliberately imperilled other activists for 
their own gain. These sixteen reports are also surprising by the openly empathetic attitude of the officers of the Polish Information Agency in Vilnius towards a majority of the figures being described (including Boris Kletskin).

\section{0бразы ведущих белорусских деятелей в свете сообщений Управления Комиссара Правительства для города Вильно В 1924 г. Аннотация}

В специфической политической обстановке, царствующей на северо-восточных землях в 1923-1924 гг. Департамент безопасности (Информационное отделение) Министерства внутренних дел в Варшаве осенью 1923 г. направил запрос к Делегату Правительства в Вильно об предоставлении информации на тему ведущих виленских белорусских деятелей. В наследии Делегата Правительства в Вильно автор работы нашла характеристики пятнадцати, не только виленских, белорусских деятелей: Всеволода Бильдзюкевича, Клавдия Дуж-Душевского, Фабиана Яремича, Михаила Кохановича, Арсения Кончевского, Михаила Красинского, Юзефа Логиновича, Антона Луцкевича, Юзефа Мамоньки, Радослава Островского, Михиала и Франтишка Петкевичей, Василия Рагули, Сымона Рак-Михайловского и Владимира Самойло. К ним было добавлено сообщение о поддерживающем белорусское движение в Вильно еврее Клецкине.

Агенты не сообщали, в принципе, никакой информации, касающейся текущих событий, зато их рассказы, записанные чиновниками, бросают новый свет на события, начиная с начала столетия, с особенным учетом персональной информации времен Первого Всебелорусского съезда (XII 1917). Ценность этих сообщений - существенна также по другим соображениям. Она позволяет выдвинуть тезис, что часть белорусских лидеров благодаря подставным информаторам белорусам намеренно компрометировала других белорусов (главным образом Мамоньку) для нужд своих текущих белорусскобелорусских споров.

Найденные шестнадцать характеристик - неожиданны, наперекор повсеместно царствующему мнению, из-за исполненного эмпатии и доброжелательности отношения чиновников польской Информационной службы в Вильно к большинству описываемых лиц (включая еврея Клецкина).

\section{Bibliography (selection)}

Bergman A., Sprawy białoruskie w II Rzeczypospolitej, Warszawa, 1984.

Gomółka K., Białorusini w II Rzeczypospolitej, Gdańsk, 1992.

Łatyszonek O., Białoruskie formacje wojskowe 1917-1923, Białystok, 1995.

Michaluk D., "Jestem przyjacielem Białorusinów - raporty wywiadowcze Romualda Ziemkiewicza do II Oddziału Sztabu Generalnego WP z lat 1922-1923”, ed. D. Michaluk, Białoruskie Zeszyty Historyczne, 25 (2006), pp. 209-258.

Michaluk D., "Jestem przyjacielem Białorusinów - raporty wywiadowcze Romualda Ziemkiewicza do II Oddziału Sztabu Generalnego WP z lat 1922-1923”, ed. D. Michaluk, Białoruskie Zeszyty Historyczne, 26 (2006), pp. 236-280.

Mironowicz E., Białoruś, Warszawa, 1999.

Mironowicz E., Białoruś, $2^{\text {nd }}$ ed.: Warszawa, 2007.

Чарнякевіч, А., Постаці беларускага нащьяянальнага руху ў Гродне 1909-1939: біяграфбічны даведнік, Мінск, 2003. 
Joanna Gierowska-Kałłaur, $\mathrm{PhD}$, professor of the Institute of History of the Polish Academy of Sciences, employee of the Section of History of Eastern Europe and Studies on $19 / 20^{\text {th }}$ Century Empires, specialises in queries and editing of sources; lecturer at the Centre for East European Studies of the University of Warsaw; currently works inter alia on the "Brief outline of the Belarusian issue", based mainly on unpublished materials from the archives of the Supreme Command of the Polish Army at the Trofeynyy Fond in Moscow (j.gierowska-kallaur@uw.edu.pl). 